\title{
Biogeochemical responses of two alpine lakes to climate change and atmospheric deposition, Jasper and Banff National parks, Canadian Rocky Mountains
}

\author{
William O. Hobbs, Rolf D. Vinebrooke, and Alexander P. Wolfe
}

\begin{abstract}
The sensitivity of remote alpine ecosystems to global change has been documented by 20th century changes in climate, glacial recession, and terrestrial and aquatic ecosystems. Here we present sedimentary records of biogeochemical responses in two alpine lake ecosystems to multiple environmental drivers over the last $~ 500$ years in Banff and Jasper National Parks (Alberta, Canada). We combine paleoecological measures of primary production and diatom community structure with geochemical proxies of reactive $\mathrm{N}(\mathrm{Nr})$ deposition to describe the nature and rate of recent ecosystem changes. Curator Lake in Jasper shows a strong diatom response to the limnological effects of climate warming (e.g., thermal stratification), but little evidence of changes in $\mathrm{Nr}$ cycling over the last 500 years. The response of McConnell Lake in Banff to climate change is strongly mediated by glacial activity within the catchment and changing inputs of Nr. Our findings highlight the range of limnological responses that may be expressed by similar ecosystems subjected to comparable abiotic stressors, while further documenting the magnitude of the ecological footprint associated with recent environmental change in mountain park environments.
\end{abstract}

\begin{abstract}
Résumé : La sensibilité des écosystèmes alpins éloignés au changement global a été démontrée par les modifications produites au cours du $20^{\mathrm{e}}$ siècle dans le climat, dans le retrait des glaciers et dans les écosystèmes terrestres et aquatiques. Nous présentons ici des enregistrements sédimentaires de réponses biogéochimiques de deux écosystèmes lacustres alpins aux multiples facteurs de changement du milieu au cours des derniers 500 ans dans les parcs nationaux de Banff et de Jasper (Alberta, Canada). Nous combinons des mesures paléoécologiques de la production primaire et des analyses de structure des communautés de diatomées à des variables géochimiques de remplacement du dépôt de $\mathrm{N}$ réactif $(\mathrm{Nr})$ afin de décrire la nature et le taux des changements récents à l'écosystème. Le lac Curator à Jasper montre une forte réponse des diatomées aux effets limnologiques du réchauffement du climat (par ex., la stratification thermique), mais peu d'indications de changements dans le recyclage de $\mathrm{Nr}$ au cours des derniers 500 ans. La réponse du lac McConnell à Banff au changement climatique est fortement influencée par l'activité glaciaire au sein du bassin versant et par les apports changeants de Nr. Nos résultats soulignent l'étendue des réponses limnologiques qui peuvent être exprimées par des écosystèmes semblables soumis à des facteurs abiotiques de stress comparables; ils apportent des informations additionnelles sur l'importance de l'empreinte écologique associée au changement récent dans les environnements montagneux des parcs.
\end{abstract}

[Traduit par la Rédaction]

\section{Introduction}

Alpine lakes are both sentinels and integrators of anthropogenic environmental change, despite their remote locations (Williamson et al. 2009). Profound ecological shifts in the ecosystems of alpine lakes have occurred during the 20th century (Parker et al. 2008; Hobbs et al. 2010a). Cumulative impacts of environmental changes on aquatic systems can be confounded by antagonistic and synergistic interactions among stressors (Vinebrooke et al. 2004). It therefore becomes necessary to expect synergistic responses of alpine lakes to regionally diffuse stressors such as climate change and the atmospheric deposition of nutrients. However, with a general lack of long term monitoring data on alpine lakes, it is often not possible to decipher how aquatic ecosystems have responded to stressors through time on a decadal to centennial scale. The careful interrogation of lake sediment records, paleolimnology, can be used to provide ecological trends and answers to questions of ecosystem response (Smol 2010). Geochemical and subfossil biological remains of the aquatic ecosystem are generally well preserved in lake sediments. Alpine lakes are well suited for paleolimnological

Received 21 September 2010. Accepted 25 March 2011. Published at www.nrcresearchpress.com/cjfas on xx August 2011. J22026

Paper handled by Associate Editor Gesa Antoine Weyhenmeyer.

W.O. Hobbs* and A.P. Wolfe. Department of Earth and Atmospheric Sciences, University of Alberta, Edmonton, AB T6G 2E3, Canada. R.D. Vinebrooke. Department of Biological Sciences, University of Alberta, Edmonton, AB T6G 2E9, Canada.

Corresponding author: William O Hobbs (e-mail: whobbs@smm.org).

*Present address: St. Croix Watershed Research Station, 16910 152nd Street North, Marine-on-St. Croix, MN 55047, USA. 
studies of recent environmental change, as they are headwater ecosystems having small catchments relatively unaffected by local human perturbations. Therefore the signal to noise ratio of external anthropogenic stressors is considerably higher than lower elevation lakes. There are few paleolimnological investigations of lakes in the Canadian Rocky Mountains and they have focused mainly on long-term environmental change over millennial timescales, inferred from sedimentology and diatoms (Reasoner and Hickman 1989; Desloges and Gilbert 1995; Karst-Riddoch et al. 2005). Further background on paleolimnological approaches and the specific proxies used in this paper can be found in Last and Smol (2001) and Smol et al. (2001).

Climate history of the Canadian Rocky Mountains over the last 500 years has varied both spatially and temporally, inferred mainly through glacial geomorphology and dendroclimatology (Luckman 2000). The Little Ice Age (LIA), known as the Cavell Advance in the Canadian Rocky Mountains, represents a period of glacier fluctuations due to cold temperatures and increased precipitation, which began in the 13th century. The regional timing of the maximum glacial extent during the LIA varies from the early 18th century in the north (Jasper National Park, Alberta) to the mid-19th century in the south (Banff National Park, Alberta) (Luckman 2000). General culmination of the LIA occurred during the late 1800s and, while glacial response was asynchronous, the ablation and demise of many alpine glaciers in the Canadian Rocky Mountains has continued throughout the 20th and 21st centuries, with late 20th century global warming as a strong driver (Watson and Luckman 2004; Schindler and Donahue 2006).

Since the mid-1900s, the global flux of $\mathrm{N}$ to the atmosphere from industrial fixation has been more than the sum of all natural processes (Falkowski et al. 2000; Davidson 2009). In many alpine regions of North America and Europe, the deposition of anthropogenic reactive $\mathrm{N}$ (hereinafter Nr; comprising all biologically, photochemically, and radiatively active nitrogenous compounds in the atmosphere and biosphere; Galloway et al. 2004) has stimulated algal growth and significant compositional shifts in algal communities (Wolfe et al. 2003; Bergström and Jansson 2006; Elser et al. 2009a). The potential for atmospheric deposition of $\mathrm{Nr}$ has been considered low in the Canadian Rocky Mountains (Schindler et al. 2006), and more recently, survey- and bioassay-based tests confirm that $\mathrm{N}$ limitation is rare in lakes of this region (Murphy et al. 2010). Similarly, sediment diatom assemblages in alpine lakes immediately south of the Canada-USA border suggest that $\mathrm{Nr}$ deposition rates have not reached levels attained in the southern USA Rocky Mountains (Saros et al. 2011). However, terrestrial critical loads for $\mathrm{Nr}$ deposition have been exceeded in this region and atmospheric deposition of industrial pollutants have been documented in lake sediments (Landers et al. 2008).

In this study we combine paleoecological measures of algal production (sedimentary pigments) and community structure (fossil diatoms) with geochemical proxies of $\mathrm{Nr}$ deposition (stable $\mathrm{N}$ isotopes), sedimentology, and instrumental climate data to describe the response of two alpine lakes in the Canadian Rocky Mountains over the last 500 years. We consider whether biotic changes are occurring in concert with climate change and ask whether climate is the sole driver of ecological change. We found that multiple abiotic drivers can be disentangled from the sediment record when taking into account the mediating influence of catchment processes, in particular glacial activity.

\section{Materials and methods}

\section{Study sites}

Curator Lake $\left(52.79^{\circ} \mathrm{N}, 117.86^{\circ} \mathrm{W}\right)$ is situated in Jasper National Park, Alberta, Canada, south of Jasper townsite, within the Maligne Mountain Range (Fig. 1; Table 1). It is a deep, fishless, dilute. and alkaline alpine lake with an area of $0.05 \mathrm{~km}^{2}$ (Table 1). There are no discernible inlets to the lake, suggesting that groundwater flow and interactions with talus are hydrologically important. One outlet, at the southern end of the lake, is a tributary to the Athabasca River. The small catchment has a morphology typical of alpine cirque basins (Fig. 2), but is unusual owing to its southern aspect (Fig. 1). There is currently no glacial ice visible within the catchment, however, two rock-glacierized debris flow lobes are visible on talus of the eastern and western slopes (Fig. 2). The Curator Lake catchment contains no obvious LIA terminal moraine. Centre Glacier, which lies approximately $4 \mathrm{~km}$ to the northwest, reached a LIA maximum at $1500 \mathrm{AD}$, and additional morainal deposits are present from 1650, 1808, 1862, and 1915 (Luckman 2000). Bedrock geology of the catchment includes Miette Group (Ediacaran) argillaceous sandstone and conglomerates, and minor dolomite and limestone. However, given the alkalinity and $\mathrm{pH}$ of the lake, it would seem that surrounding Lower Paleozoic bedrock, consisting mainly of thick-bedded limestone and dolomite, has a stronger influence on the chemistry of Curator Lake. The basin is primarily talus and bedrock, with a small area of vegetation adjacent to the eastern shore of the lake, which includes grasses, mosses, and lichens.

McConnell Lake $\left(51.63^{\circ} \mathrm{N}, 115.98^{\circ} \mathrm{W}\right)$ is located in Banff National Park, Alberta, north-northwest of the Banff townsite, within the Vermillion Range (Fig. 1). Like Curator Lake, it is deep, fishless, dilute, and alkaline, with a similar lake area of $0.08 \mathrm{~km}^{2}$ (Table 1). However, McConnell Lake has a much larger catchment than Curator Lake, with a northern aspect (Fig. 1). Bedrock geology of the catchment is Lower Paleozoic pale grey thick-bedded dolomite and limestone with calcareous and siliceous shales and local conglomerates. A cirque basin, occupied by a glacier during the LIA and currently contains a perennial snowpack, is perched to the south of McConnell Lake (Fig. 2). The catchment also extends to the west and contains perennial snowpack (Fig. 1). The complete LIA geomorphic activity has not been established for this basin; however, the nearby Drummond Glacier is thought to have reached a LIA maximum in the late 16th to mid-17th century (Luckman 2000). Changes in sedimentation to the nearby Hector Lake during glacial transitional periods suggest advances during the early 1700 s and 1800 s with rapid glacial recession in the early 20th century (Leonard 1997). A visible surface water input from the cirque basin enters the lake from the south, whereas the outlet to the lake is at the northern end (Fig. 2). The lake is a headwater system for McConnell Creek, which drains into the Red Deer River. The catchment is sparsely vegetated $(<\sim 10 \%)$ with shrubs, grasses, mosses, and a small copse of 
Fig. 1. (a) Location of study sites. Approximate extent of the Rocky Mountain Range shaded in grey. Relevant national park boundaries for Jasper National Park (JNP), Canada; Banff National Park (BNP), Canada; and Glacier National Park (GNP), USA. (b) Topography of the Curator Lake basin, JNP with approximate area of the lake catchment shown with dashed line. (c) Catchment of McConnell Lake, BNP also showing lake catchment outline. Additional details for each lake are located in Table 1.

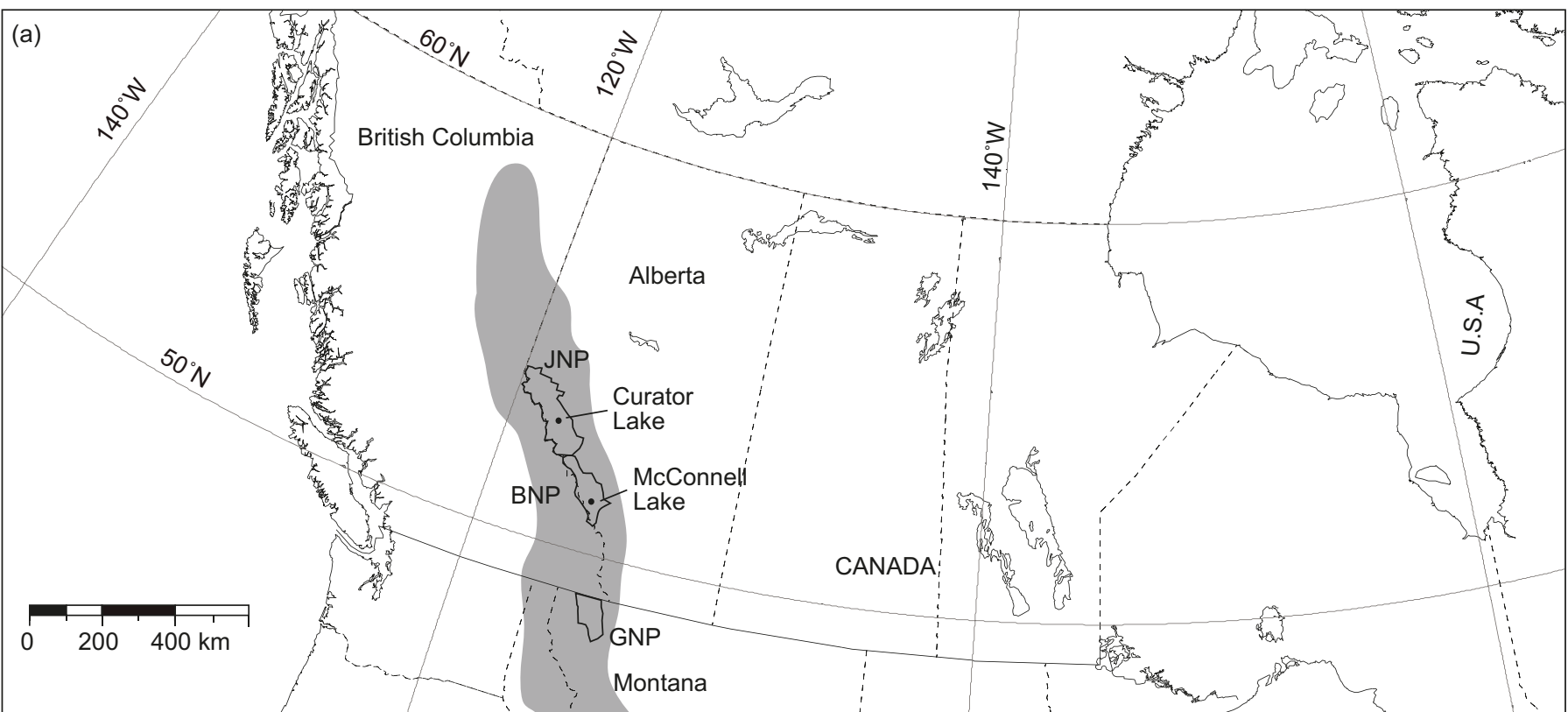

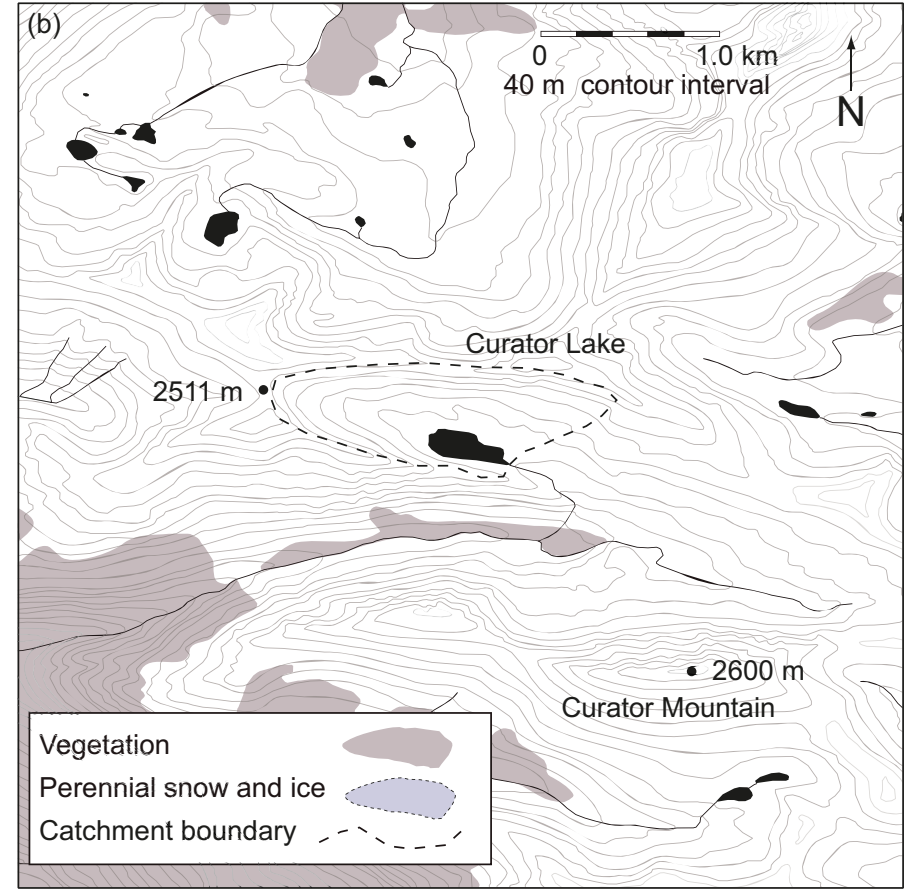

subalpine fir (Abies lasiocarpa) concentrated mainly on the western-northwestern side of the lake (Fig. 2).

\section{Sediment core collection and chronology}

A sediment core was retrieved from the deepest section of each lake (Table 1) using a Glew-type gravity corer (Glew et al. 2001). Sediment was subsampled immediately after recovery at $0.25 \mathrm{~cm}$ intervals for the first 10 and $0.5 \mathrm{~cm}$ intervals thereafter. Sediments were frozen within $24 \mathrm{~h}$ and freezedried soon after.

Geochronology was established through ${ }^{210} \mathrm{~Pb}$ decay (measured as ${ }^{210} \mathrm{Po}$ ) by alpha spectroscopy on each core (Appleby

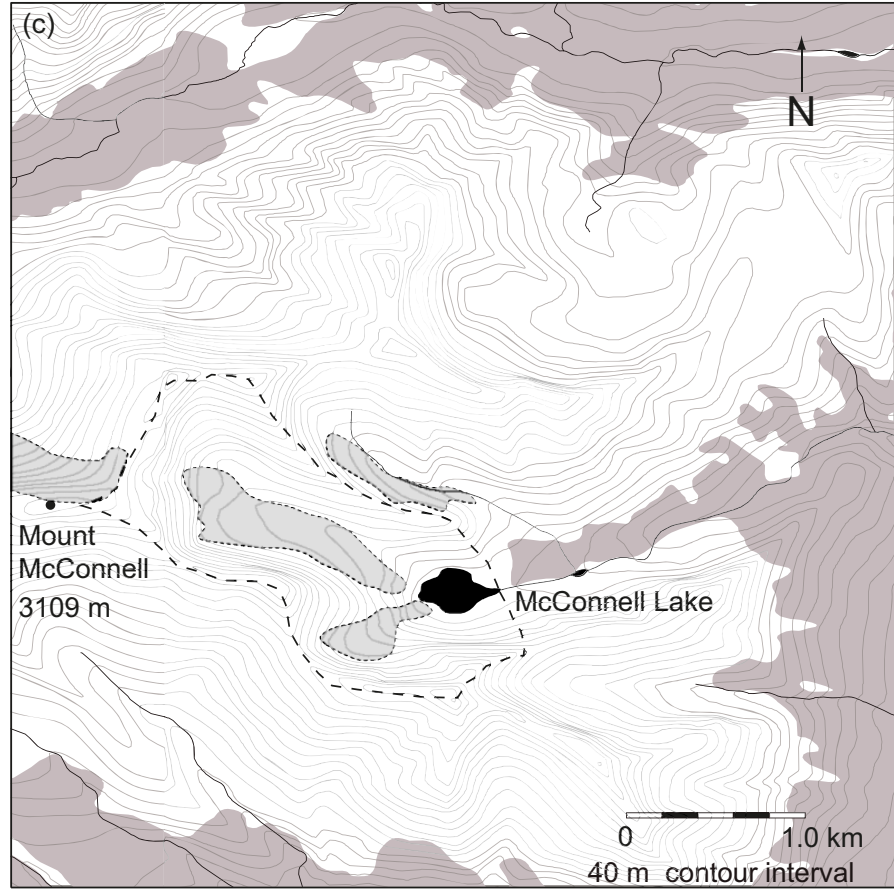

2010). The constant rate of supply (CRS) model was used to estimate ages and sedimentation rate based on the radioactive decay of excess (or unsupported) ${ }^{210} \mathrm{~Pb}$ above the background (or supported) ${ }^{210} \mathrm{~Pb}$ activity (Appleby and Oldfield 1978).

\section{Diatom microfossils}

Sediments were processed using standard techniques for the oxidation of both carbonate minerals and organic matter, and permanently mounted on slides for diatom enumeration (Battarbee et al. 2001). Diatoms were enumerated under oil immersion (numerical aperture $=1.4$ ) at a magnification of 1000x using differential interference contrast optics. Diluted 
Table 1. Lake physical characteristics and water chemistry.

\begin{tabular}{lll}
\hline & Curator Lake & McConnell Lake \\
\hline Latitude $\left({ }^{\circ} \mathrm{N}\right)$ & 52.792055 & 51.638162 \\
Longitude $\left({ }^{\circ} \mathrm{W}\right)$ & 117.862727 & 115.977579 \\
Altitude $(\mathrm{m}$ above sea level) & 2232 & 2300 \\
Lake area $\left(\mathrm{km}^{2}\right)$ & 0.05 & 0.08 \\
Catchment area $\left(\mathrm{km}^{2}\right)$ & 0.8 & 2.7 \\
Catchment : lake area & 15.8 & 33.6 \\
Maximum depth $(\mathrm{m})$ & 25 & 31 \\
$\mathrm{pH}$ & 8.4 & 8.0 \\
Conductivity $\left(\mu \mathrm{S} \cdot \mathrm{cm}^{-1}\right)$ & 220 & - \\
Turbidity $(\mathrm{NTU})$ & 0.69 & - \\
DOC $\left(\mathrm{mg} \cdot \mathrm{L}^{-1}\right)$ & - & 0.6 \\
$\mathrm{NO}{ }^{-1}-\mathrm{N}\left(\mu \mathrm{g} \cdot \mathrm{L}^{-1}\right)$ & 66.5 & 129 \\
Total N $\left(\mu \mathrm{g} \cdot \mathrm{L}^{-1}\right)$ & 269 & 184 \\
Total P $\left(\mu \mathrm{g} \cdot \mathrm{L}^{-1}\right)$ & 3.98 & 3.00 \\
DIN:TP & 37 & 92 \\
TN:TP & 150 & 131 \\
\hline
\end{tabular}

Note: Water chemistry represents a single sample integrating the photic zone waters, taken during the summer of 2007. NTU, nephelometric turbidity unit; DOC, dissolved organic carbon; DIN:TP, dissolved inorganic nitrogen - total phosphorus molar ratio; TN:TP, total nitrogen - total phosphorus molar ratio.

slurries were spiked with a known quantity of exotic pollen grains for calculating absolute microfossil concentration (Wolfe 1997). A range of published diatom floras were consulted for species identification (Krammer and Lange-Bertalot 1986, 1988, 1991a, 1991b; Wunsam et al. 1995; Fallu et al. 2000; Cremer et al. 2001; Moser et al. 2004), and photomicrographic documentation was conducted throughout the study using both light and scanning electron microscopy. We refer to the Cyclotella comensis "complex" throughout the paper, which is comprised of ecologically compatible, very small $(\sim 5 \mu \mathrm{m})$ morphotypes of Cyclotella comensis Grunow that cannot be further resolved by light microscopy. We used scanning electron microscopy to confirm the presence and defining characteristics of a singular central fultoportula and valve face rimoportula on specimens in both valve and dorsal views.

Diatom microfossils showed some signs of dissolution throughout both cores, which is common in other Canadian Rocky Mountain lakes given the low Si availability, alkaline $\mathrm{pH}$, and strong microbial alteration of protective organic coatings covering diatom cells (Hobbs et al. 2010b). To verify that our stratigraphic trends in diatom assemblages are not being shaped by diagenetic effects, we calculated the $F$ index ratio of Flower and Likhoshway (1993), which is a dissolutional index and has been rigorously tested in laboratory and field settings (Ryves et al. 2001). We then used linear regression to test whether the $F$ index explained a statistically relevant portion of the trends in diatom communities.

\section{Geochemistry}

The composition of the sediments was established using loss-on-ignition (Heiri et al. 2001). Percent organic matter (\% OM) was attained by combustion at $550{ }^{\circ} \mathrm{C}$, percent carbonate- $\mathrm{C}\left(\% \mathrm{CO}_{3}\right)$ at $1000{ }^{\circ} \mathrm{C}$, with remaining mass representing the noncarbonate inorganic fraction. Samples of sediment organic matter were analyzed for stable $\mathrm{N}$ isotopes $\left(\delta^{15} \mathrm{~N}\right.$; ratio of ${ }^{15} \mathrm{~N}:{ }^{14} \mathrm{~N}$ as per mil $(\% o)$, relative to air $\left.(0 \% \circ)\right)$
Fig. 2. Photographs of Curator Lake (a), McConnell Lake (b), and their surrounding catchment. Two rock-glacierized talus slopes flank Curator Lake, whereas recently (post-Little Ice Age) deglaciated terrain occupies the upper cirque above McConnell Lake. Photo credits: (a) W.O. Hobbs, August 2006, and (b) R.D. Vinebrooke, July 2007.
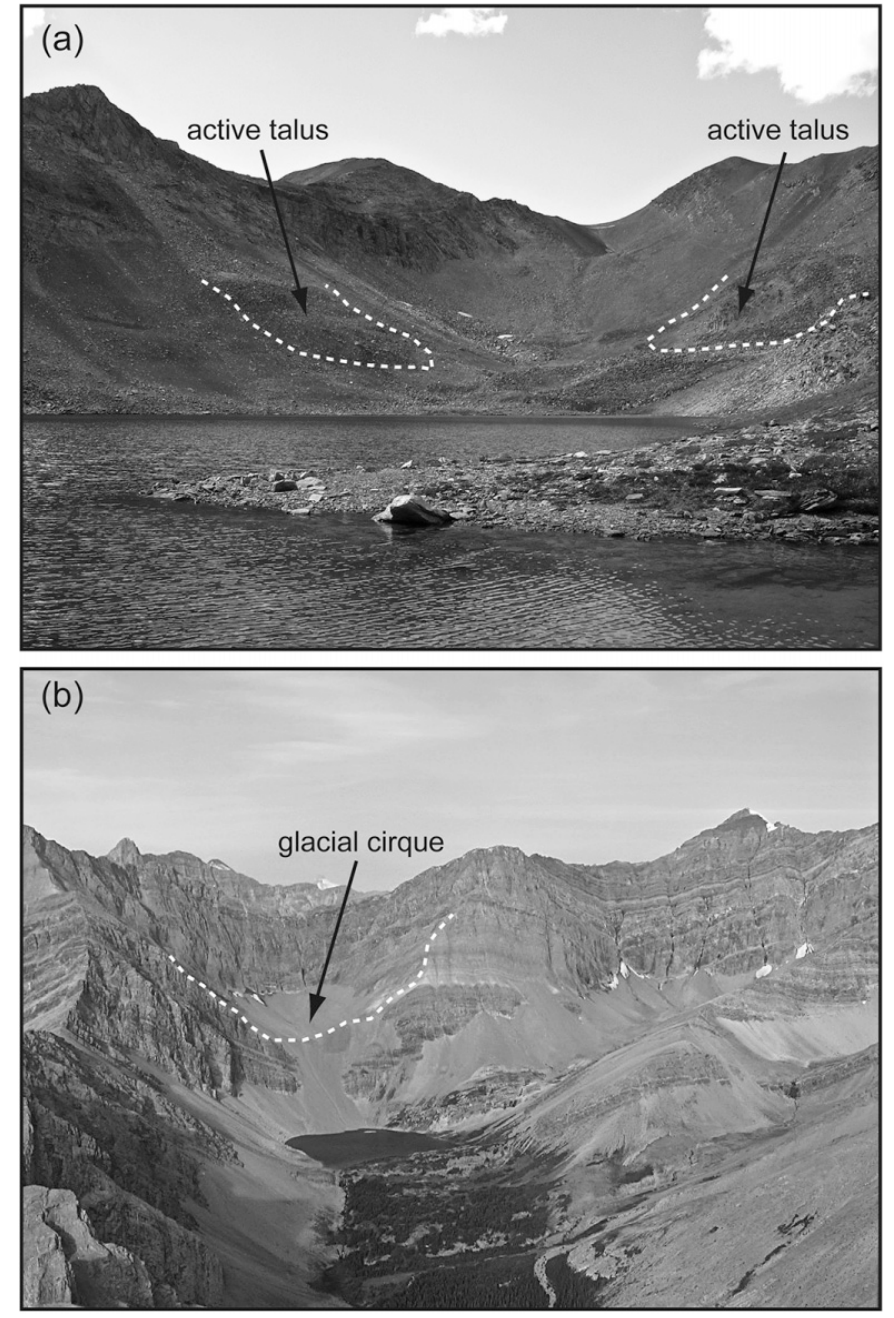

using an elemental analyzer interfaced to a continuous flow isotope-ratio mass spectrometer at the University of CaliforniaDavis, Stable Isotope Facility, . Both wet and dry deposition of $\mathrm{N}$ with a depleted $\delta^{15} \mathrm{~N}$ signature from fossil fuel and fertilizer $\mathrm{NO}_{\mathrm{x}}$ emissions (including agricultural nitrification) can be assimilated by alpine lake ecosystems and recorded by lake sediments (Wolfe et al. 2003; Enders et al. 2008).

\section{Microbial pigments}

Pigments were quantified using standard reverse-phase high-pressure liquid chromatographic (HPLC) techniques specifically developed for lake sediments (Vinebrooke et al. 2002). Pigments were first extracted from freeze-dried sediments using an acetone-methanol solution. Extracts were then filtered $\left(0.2 \mu \mathrm{m}\right.$ pore nylon), dried under $\mathrm{N}_{2}$, and reconstituted using a precise volume of injection solution. Chromatographic separation was performed with an Agilent 1100 Series HPLC equipped with a Varian Microsorb $100 \AA$ $(1 \mathrm{~A}=0.1 \mathrm{~nm}) \mathrm{C} 18 \mathrm{column}$, and pigment detected using inline diode array and fluorescence detectors. Pigment concen- 
trations are quantified via calibration equations and an electronic spectral library constructed using standards purchased from DHI Water and Environment (Agern Alle 5, DK-2970 Hørsholm, Denmark). HPLC chromatograms were also compared to Jeffrey et al. (2005), a key reference for taxonomically diagnostic pigments. All pigment concentrations were normalized to sediment organic matter. Owing to the potential for pigment diagenesis in this environment (Hobbs et al. $2010 b$ ), we have cautiously created the following summary fractions: total chlorophylls (Tchl: all primary chlorophylls and derived pheopigments) and total diatom carotenoids (TDC: fucoxanthin and diatoxanthin).

\section{Numerical analyses}

Detrended correspondence analysis (DCA) was used to summarize the dominant gradient (i.e., DCA axis 1) of diatom compositional turnover (Hill and Gauch 1980). All diatom species were included in the analysis, detrending was by segments with down-weighting of rare taxa, and nonlinear rescaling was applied. When plotted stratigraphically, the DCA axis 1 scores show the amount of turnover between samples over time in units of standard deviation (SD). However, this is not an estimate of the rate at which compositional change is occurring because the DCA is independent of sediment chronology. We determined the rate-of-change by linearly interpolating diatom percent abundance and pigment concentration data to exactly 10-year and 5-year intervals, respectively, and calculating the dissimilarity between adjacent samples (Jacobson and Grimm 1986; Lotter et al. 1992). Pigment concentration data was $\log _{10}(x+1)$ transformed prior to dissimilarity calculations to stabilize variance within each data set. Dissimilarity was measured by Euclidean distance for the pigment data and chord distance for the diatom data, as appropriate for concentration and percent abundance data, respectively (Hall et al. 1999). The dissimilarity metrics were then divided by the amount of time between samples, giving a rate-of-change. While we do not present all sedimentary pigment data, rate-of-change calculations are based on complete chlorophyll and carotenoid results for both lakes (R.D. Vinebrooke, unpublished data). The rate-of-change of the diatom assemblage and sedimentary pigments can be interpreted as a measure of the stability of both communities through time. Interpolations were carried out using AnalySeries 2.0 (Paillard et al. 1996), while DCA and dissimilarity distances were calculated using $\mathrm{R}$ ( $\mathrm{R}$ Development Core Team 2010). We express diatom species richness as the number of species per sediment interval predicted by rarefaction analysis, normalized to a count size of 400 valves $\left(E\left(S_{400}\right)\right)$ (Birks and Line 1992).

We used simple multiple linear regression to test relationships among biological response variables (diatom DCA axis 1, log transformed pigment concentrations, and square-root transformed diatom species abundances) and explanatory climate variables (mean annual temperature, mean winter temperature (October-May), mean maximum winter temperature (October-May), mean minimum winter temperature (OctoberMay), mean summer temperature (June-September), mean maximum summer temperature (June-September), mean minimum summer temperature (June-September), mean winter snowfall, and spring rainfall). Instrumental data was averaged over each sediment interval. Instrumental climate data sets were acquired online from the National Climate Data and Information Archive, Environment Canada, for the Banff townsite (1888-present) and the Jasper townsite (1947-present). Both climate data sets are continuous and raw instrumental data was used in the analyses.

\section{Results}

\section{Climate records}

Instrumental temperature anomalies (relative to the 19611990 climate normals) since 1937 for the Jasper townsite show a warm period ca. 1940 followed by cooling until 1950 and then a steady increasing trend with the post-1980 period warmer than average (Fig. 3). Winter precipitation records for Jasper are highest during the cool mid-20th century, with a decreasing trend starting in the late 1970s. At the Banff townsite, climate records extend back to 1888 and show that the 20th century is generally cooler than average with the exception of the 1980s. Similar to Jasper, the winter precipitation for Banff is greatest during the period $~ 1950$ 1970 (Fig. 3). To extend the climate record beyond the 20th century, we rely on the dendro-climatic reconstruction of Luckman and Wilson (2005), which is a compilation of records from the Banff and Jasper regions. This record shows the post-LIA warming at the end of the 19th century and through the 20th century, with post-1980s climate the warmest over the last 500 years (Fig. 3).

\section{Core chronologies}

Both sediment cores were reliably dated and generally showed slow conformable sedimentation rates over the last 200 years (Fig. 4). In Curator Lake, supported ${ }^{210} \mathrm{~Pb}$ (background) was reached at a depth of $7 \mathrm{~cm}$ and the average drymass sedimentation rate for the lake is $11.7 \mathrm{mg} \cdot \mathrm{cm}^{-2} \cdot y e a r^{-1}$. McConnell Lake showed some variation in the decay of ${ }^{210} \mathrm{~Pb}$, suggesting slight sediment mixing or an increase in sedimentation, which would dilute ${ }^{210} \mathrm{~Pb}$ activity (Fig. 4). We observe an increase in percent carbonate composition of the sediments associated with these variations, which suggests an increase in inorganic deposition and dilution of the ${ }^{210} \mathrm{~Pb}$ activity. Therefore, we are confident the chronology established for McConnell Lake is reliable. The supported level of ${ }^{210} \mathrm{~Pb}$ was reached at a depth of $10 \mathrm{~cm}$ and the mean drymass sedimentation rate is $24.5 \mathrm{mg} \cdot \mathrm{cm}^{-2}$.year ${ }^{-1}$. Mean sedimentation rates are based on estimated sedimentation rates from the section of the core where organic content is relatively constant (below $6 \mathrm{~cm}$ in McConnell Lake and below $3 \mathrm{~cm}$ in Curator Lake). We were unable to locate any terrestrial fossils that would be appropriate for ${ }^{14} \mathrm{C}$ dating to extend our chronology beyond the $\sim 150$ year limit of ${ }^{210} \mathrm{~Pb}$ dating. The uncertainties of radiocarbon dates using pollen or bulk sediment in a carbonate lake catchment are numerous (e.g., reservoir effect and low pollen abundance) and we did not consider this a viable option. We therefore employed the approach of Binford (1990) and extrapolated the ${ }^{210} \mathrm{~Pb}$ model using the mean sedimentation rate. While we recognize the limitations of this method, we note that the dry bulk density $\left(\mathrm{g} \cdot \mathrm{cm}^{-3}\right)$ has stabilized below the dated sections of both cores (McConnell Lake $495 \pm 73 \mathrm{mg} \cdot \mathrm{cm}^{-3}$; Curator Lake $447 \pm$ $\left.68 \mathrm{mg} \cdot \mathrm{cm}^{-3}\right)$. 
Fig. 3. Instrumental and dendro-climatic records for the Canadian Rocky Mountains. Instrumental data from the National Climate Data and Information Archive, Environment Canada. Data presented for the Jasper townsite: (a) mean annual temperature, expressed as anomaly relative to the 1961-1990 normal (MAT); and (b) mean winter snowfall (MWS). Data for the Banff townsites shown in (c) MAT and (d) MWS. All data smoothed with a locally weighted scatterplot smoothing span of 0.2. (e) Dendroclimatic records from Luckman and Wilson (2005) showing the mean summer maximum temperature anomalies relative to the period 1901-1980, smoothed with a cubic spline with $\mathrm{df}=50$.
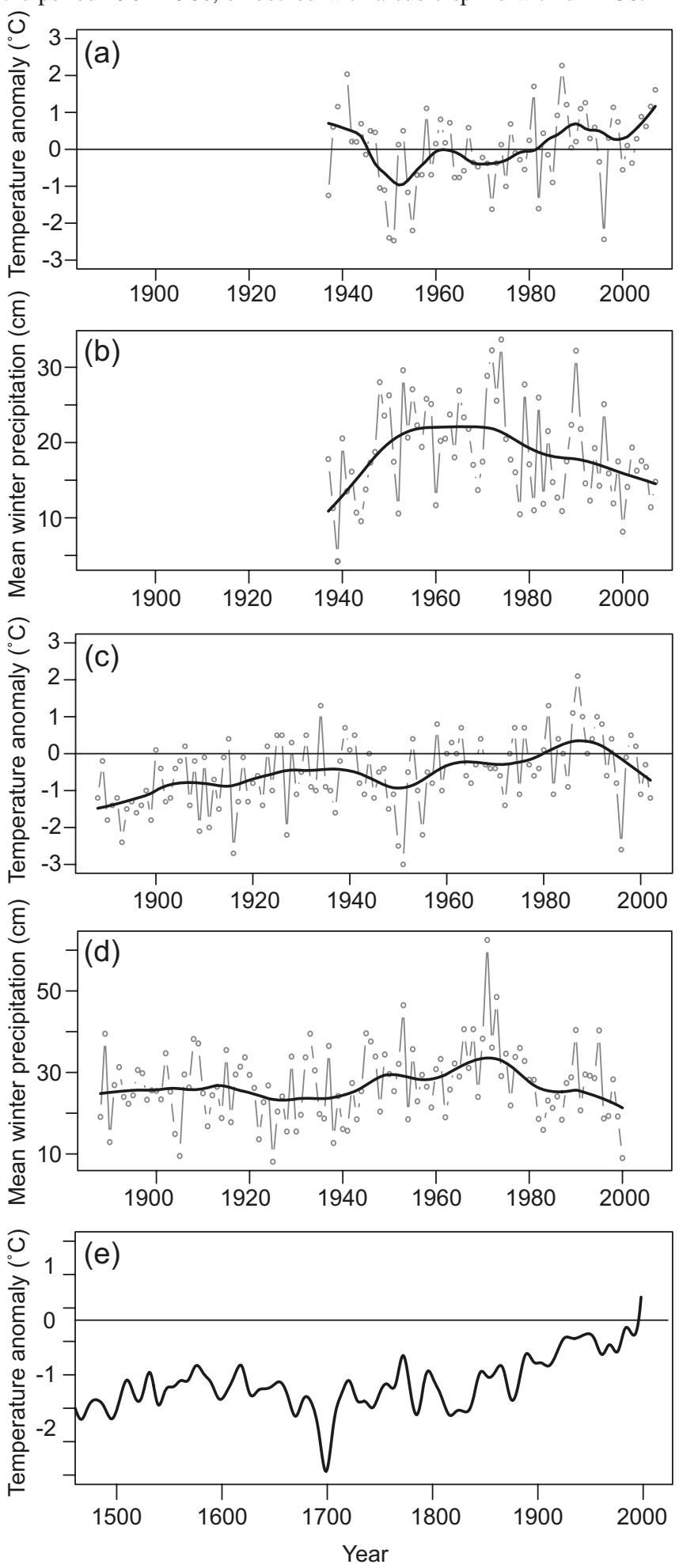

\section{Diatom communities}

We found no evidence that silica dissolution controls trends in diatom microfossil abundance or assemblage composition. No statistically significant relationships exist between the $F$ index and diatom valve concentrations or species richness in either lake. Indeed, both lakes show dominance by the Cyclotella comensis complex, a genus that has shown relatively low resistance to dissolution (Ryves et al. 2001). We do, however, find a highly significant relationship between diatom concentrations and the primary diatom carotenoid, fucoxanthin, in Curator Lake $(r=0.88, p=1.44 \times$ $10^{-6}$, df $=16$ ), suggesting that both the physical and biochemical remains of diatom assemblages are well preserved. In contrast, primary diatom pigments are absent in sediments from McConnell Lake.

Diatom communities in both lakes are very similar in species composition and richness (Fig. 5 and Fig. 6). The dominant planktonic species are small $(\sim 5 \mu \mathrm{m})$ forms within the Cyclotella comensis complex (Fig. 7). The benthic species are dominated by colonial tychoplanktonic-benthic Fragilariaceae (Staurosirella pinnata, Staurosira construens, Pseudostaurosira pseudoconstruens, Pseudostaurosira brevistriata, and Synedra parasitica) (Fig. 7). In Curator Lake, minor (1\%-5\%) abundances of the epiphytes Amphora pediculus, Amphora fogediana, and Gomphonema angustum were also present with epipelic species Eolimna minimum, Microcostatus kuelbsii, Diploneis parma, Navicula modica, and Achnanthidium minutissimum. In McConnell Lake, minor abundances of the epiphytes A. pediculus, A. fogediana, Gomphonema parvulum, and $G$. angustum were present with epipilic species Navicula cryptotenella and Denticula kuetzingii.

In both lakes the DCA axis 1 scores were strong estimators of community turnover through time (Curator Lake axis 1 explained $47.8 \%$ of the variance; McConnell Lake axis 1 explained $52.7 \%$ of the variance). The axis 1 lengths were 1.41 for Curator Lake and 1.11 for McConnell Lake, suggesting linear species responses. In both lakes the community turnover is driven by the relative success of either the Cyclotella comensis complex or the small tychoplanktonic Fragilariaceae (Fig. 5 and Fig. 6). In Curator Lake the C. comensis complex is strongly dominant ( $>50 \%$ abundance) during the recent period of 1980-present, whereas it is subdominant (20\%-35\%) during the periods $1480-1510$ and $1630-1850$. The small Fragilariaceae group is subdominant during the same time periods and strongly dominant during the periods 1510-1630 and 1850-1980. In McConnell Lake the C. comensis complex is strongly dominant for shorter time periods 1580-1600, 1680-1750, and 1910-1965, whereas the Fragilariaceae group is strongly dominant during the intervening time periods. The trends of planktonic and benthic dominance are summarized by the planktonic:benthic ratio for the two lakes (Fig. 5 and Fig. 6). The DCA axis 1 scores show that the turnover of the diatom communities over time is gradual in Curator Lake (Fig. 5), whereas the McConnell Lake communities shifted more abruptly (Fig. 6).

\section{Microbial pigments}

Large increases in photoautotrophic production during the 20th century are recorded in the total chlorophyll content of the sediments from both lakes (Fig. 5 and Fig. 6). In Curator Lake this increase in production is mainly present as chromo- 
Fig. 4. Results of ${ }^{210} \mathrm{~Pb}$ dating for $(a)$ Curator and $(b)$ McConnell lakes. Graphs, from left to right, show the total ${ }^{210} \mathrm{~Pb}$ inventories with depth, highlighting the depth of background activities. The middle graph shows the modeled sediment ages (small black circles) and calculated sedimentation rates (small black squares) with \pm 1 SD error bars. The graphs to the right show the linear relationships between unsupported ${ }^{210} \mathrm{~Pb}$ and cumulative dry mass, suggesting fairly conformable sedimentation towards the limit of ${ }^{210} \mathrm{~Pb}$ dating.
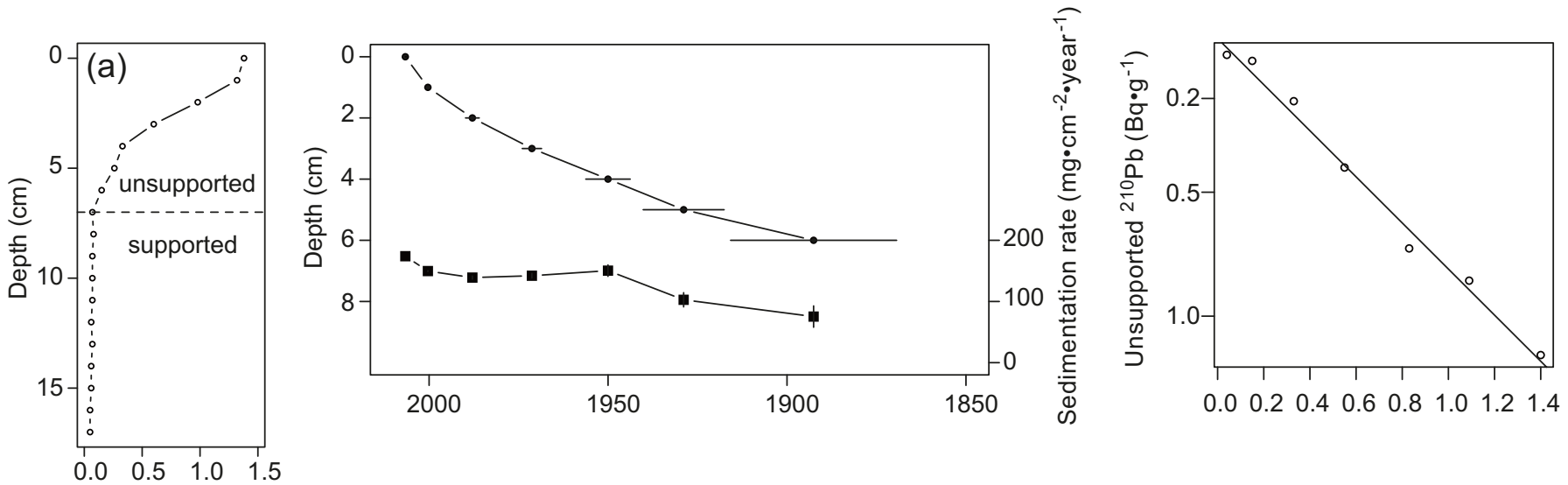
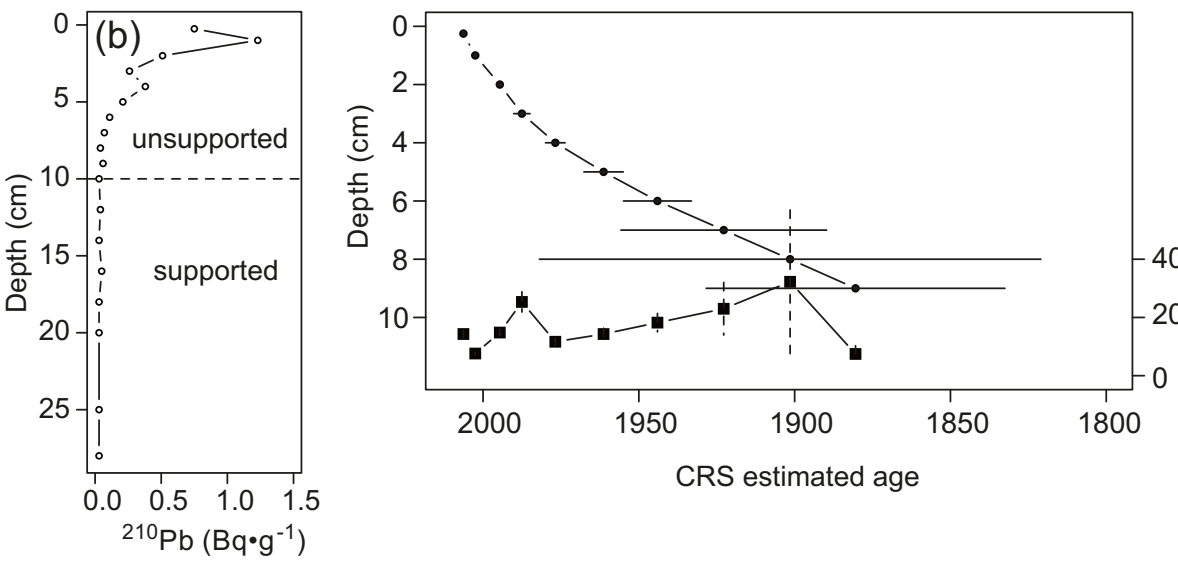

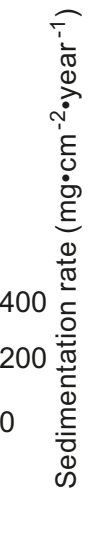

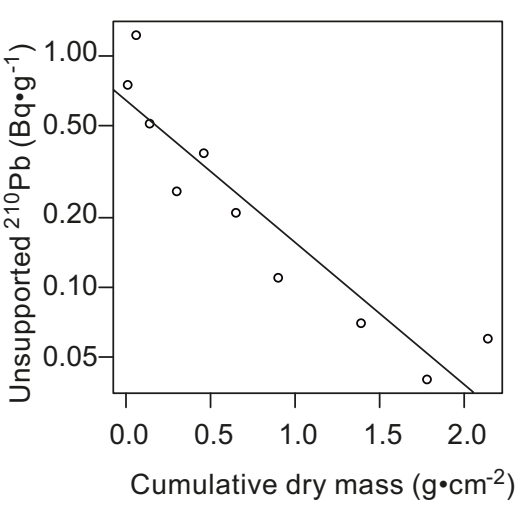

phytes (chrysophytes, diatoms, and dinoflagellates), which is also shown by the consistent trend in TDC (Fig. 5). The trend in McConnell Lake is more variable over the length of the core (Fig. 6). Vinebrooke et al. (2010) have characterized this increase in primary production as mainly due to deepwater bacteria, including planktonic green and purple sulfur groups, and picocyanobacteria (recorded as zeaxanthin). The TDC profile in McConnell Lake is possibly affected by diagenesis, given the lack of correlation with the diatom valve abundance (Fig. 6).

\section{Sediment composition and geochemistry}

Sedimentological properties of the cores are somewhat similar between the cores. In both lakes the majority of the sediment is comprised of an inorganic fraction (Curator Lake 85\%-92\%; McConnell Lake 76\%-90\%). Both lakes record an increase in \% OM during the 20th century, after $\sim 1930$ in Curator Lake (Fig. 5) and after 1910 in McConnell Lake (Fig. 6). Curator Lake ranges from $6 \%$ to $13 \%$ with a pre1930 background of $6.4 \% \pm 0.3 \%$, whereas McConnell Lake ranges from $3 \%$ to $12 \%$ with a pre-1910 background of $4.3 \% \pm 0.5 \%$. Carbonate abundance in Curator Lake is low and varies very little throughout the core $(2.0 \% \pm 0.3 \%)$, whereas McConnell Lake ranges from $9 \%$ to $18 \%$ with a mean of $12.2 \% \pm 2.5 \%$.

The $\delta^{15} \mathrm{~N}$ of sediment organic matter in Curator Lake

varies very little throughout the core with a mean of $3.46 \%$ $\pm 0.39 \%$ (Fig. 5). McConnell Lake records a very similar $\delta^{15} \mathrm{~N}$ for the pre-1910 section of the core $(3.48 \%$ \pm $0.57 \%$ ) (Fig. 6). Following $1910, \delta^{15} \mathrm{~N}$ is depleted, but remains relatively stable $(2.21 \% \circ \pm 0.21 \%$ o $)$ until 1970 when a significant monotonic depletion takes place from $2.61 \%$ to $0.65 \%$ (Fig. 6). This recent isotopic depletion is directly comparable to sediment records from lakes influenced by atmospheric deposition (Wolfe et al. 2003; Enders et al. 2008).

\section{Biological rate of change}

The rate-of-change in diatom communities and sedimentary algal pigments is greatest during the 20th century in the context of the last $\sim 500$ years (Fig. 8). In Curator Lake, the rate at which diatom communities change reflects the shifts between planktonic and benthic species, with the greatest change happening during the periods 1600-1650, 18501910, and 1980 to present. The rate at which all algal groups (as Tchl) changed is similar to the response of diatoms alone, reflecting the importance of diatoms in the whole-lake primary production in this lake. The pigment rate-of-change also shows much greater short-term variability following 1930 (Fig. 8). In McConnell Lake, the diatom and pigment rate-of-change trends are different, supporting the observation that diatoms do not dominate the whole-lake primary production (Fig. 8). The trends in McConnell Lake are also much 
Fig. 5. Biogeochemical stratigraphy of Curator Lake. Relative frequencies of dominant diatoms shown with absolute diatom concentrations and rarefaction-estimated species richness $\left[\mathrm{E}\left(\mathrm{S}_{400}\right)\right]$. The second row illustrates total diatom carotenoids (TDC), total chlorophylls $(\mathrm{Tchl})$, $\delta^{15} \mathrm{~N}$, sediment composition (percent organic matter (\% OM) and percent carbonate), and diatom community turnover as summarized by DCA axis 1 sample scores.
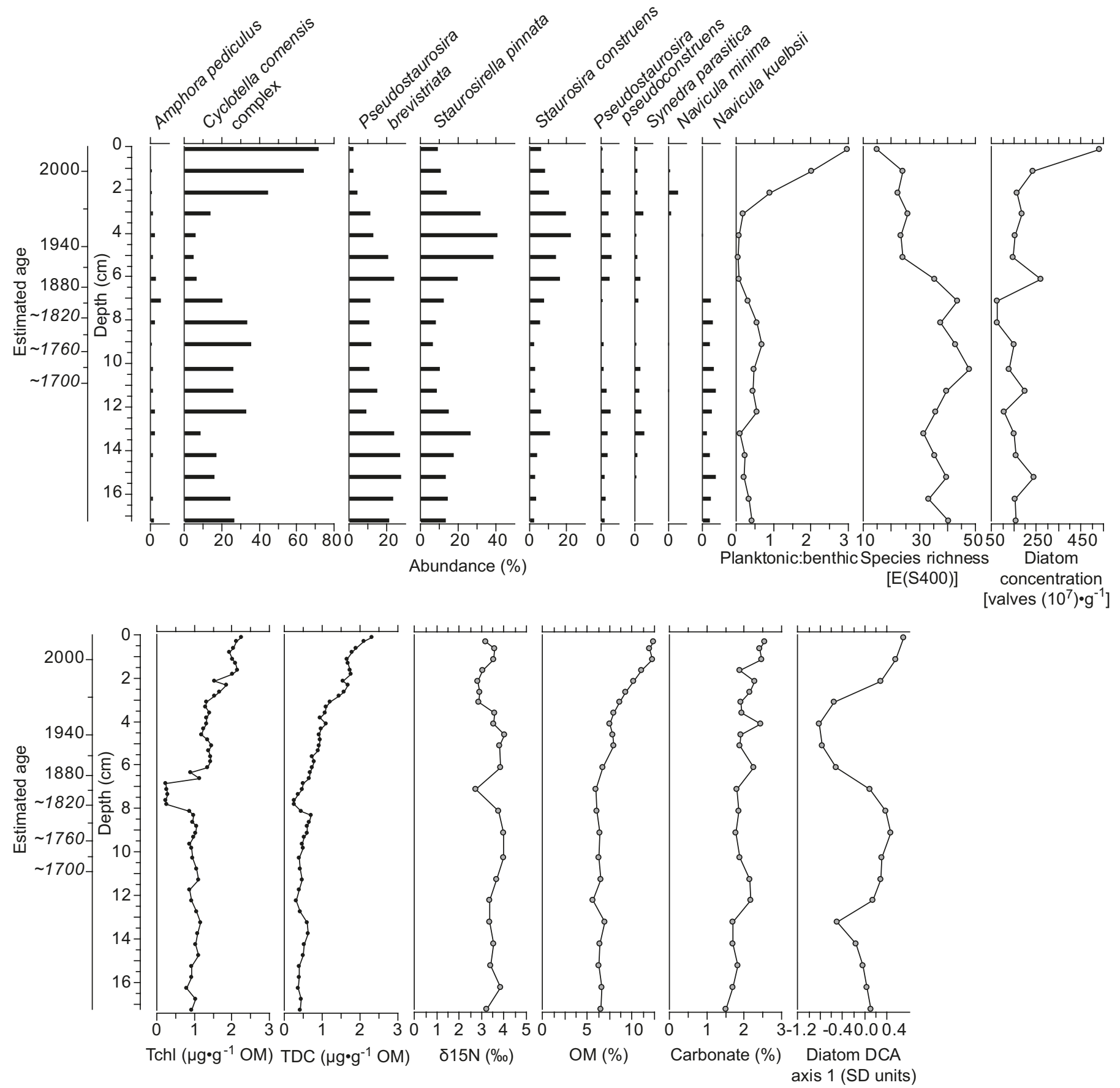

more variable over the length of the record. The greatest rateof-change recorded in the diatom communities occurs following 1910; whereas, in the pigment record the greatest rate-ofchange is within the last 20 years.

\section{Discussion}

\section{Climatic drivers of ecological change}

Profound ecological changes have occurred in the studied alpine lakes during the 20th century. Although similar shifts in photoautotrophic communities have occurred in the past, the changes in the last century are unique in both magnitude and rate, in the context of the last $\sim 500$ years. Ecological shifts in mountain lakes of the Canadian Rocky Mountains have been previously attributed to changing climate (KarstRiddoch et al. 2005; Parker et al. 2008). We see evidence of a direct influence by climate during the 20th century on the diatom assemblage turnover of Curator Lake (Fig. 9a). We found a strong linear correlation between the instrumental annual mean temperature record and diatom DCA axis $1(r=$ 
Fig. 6. Biogeochemical stratigraphy of McConnell Lake. Relative frequencies of dominant diatoms shown with absolute diatom concentrations and rarefaction-estimated species richness $\left[\mathrm{E}\left(\mathrm{S}_{400}\right)\right]$. The second row illustrates total diatom carotenoids (TDC), total chlorophylls (Tchl), $\delta^{15} \mathrm{~N}$, sediment composition (percent organic matter (\% OM) and percent carbonate), and diatom community turnover as summarized by DCA axis 1 sample scores.
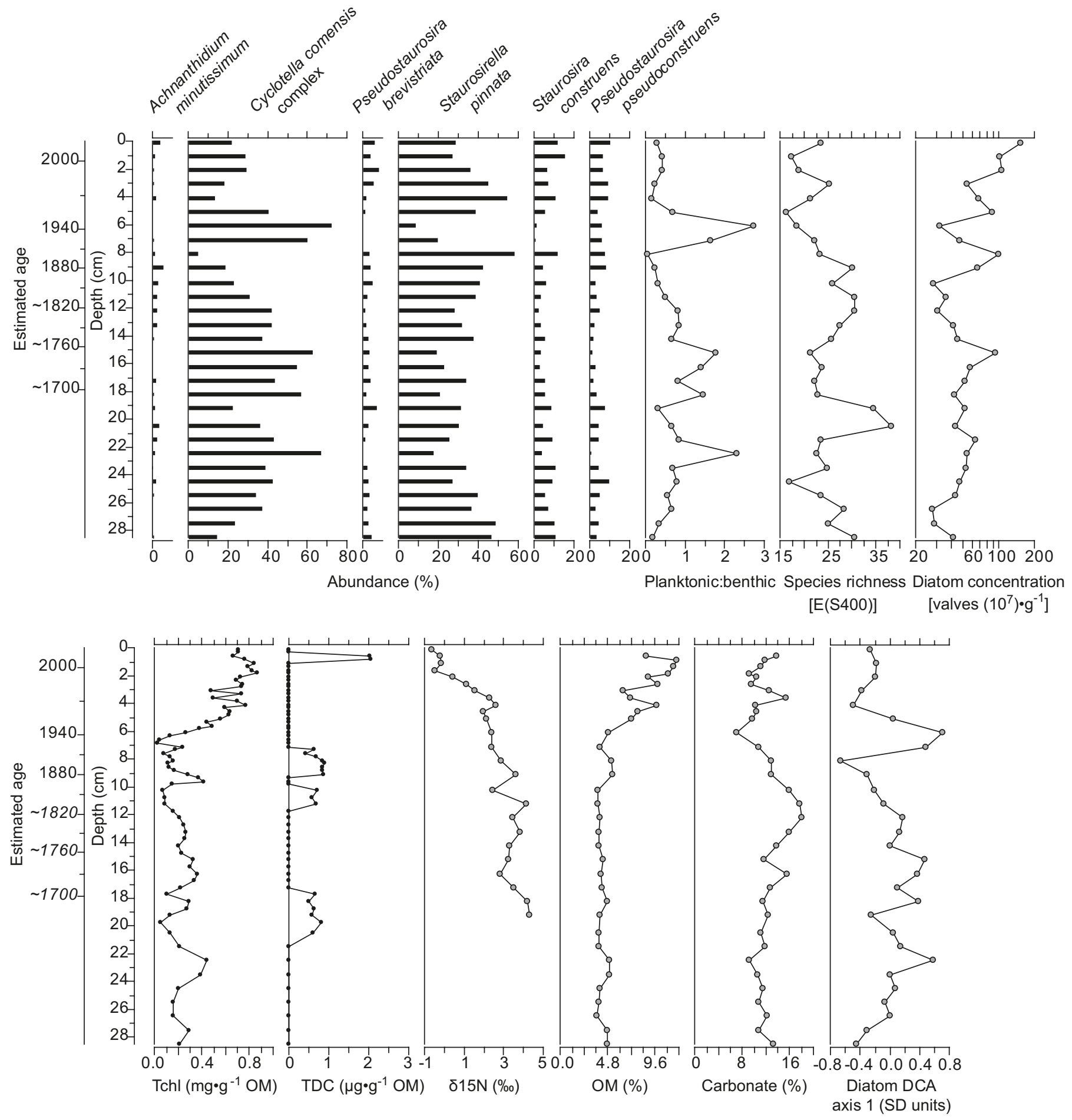

0.94; $p=0.016$ ). As temperatures have warmed through the 20th century we find a positive response from the planktonic Cyclotella comensis complex $(r=0.94 ; p=0.019)$ and a strong negative response by the small colonial Fragilariaceae $(r=-0.93 ; p=0.022)$. The proposed mechanism for this response is increasing thermal stratification (and possibly earlier onset) with warmer air temperatures, which favors the habitat of small Cyclotella species that exploit the thermocline (Rühland et al. 2008; Winder et al. 2009). This strong response to the length of ice-cover by Staurosirella pinnata, Staurosira construens, and Cyclotella species has also been recorded in seasonal sediment trap sampling in the Swiss Alps, Switzerland (Lotter and Bigler 2000). We find a significant linear correlation between annual mean temperature and 
Fig. 7. Scanning electron microscopy and light microscopy micrographs of dominant diatom taxa found in both lakes: Cyclotella comensis complex $(a-q)$ and small colonial Fragilariaceae species $\left(r-c^{\prime}\right)$, Cyclotella scale bars are $5 \mu \mathrm{m}$ and Fragilariaceae are $2 \mu \mathrm{m}$. $(a-i)$, Scanning electron microscopy images of Cyclotella comensis morphotypes showing central fultoportula(e) (cfp); marginal fultoportulae (mfp); and rimoportula(e) (rp). The valve face morphology ranges from circumferentially undulate ( $d$ and $g$ ) to radial undulations $(b)$ to a relatively smooth face $(h)$. Micrograph $(g)$ is the sole Cyclotella comensis, while the remainder of the specimens in scanning electron microscopy are $C$. cf. comensis. A singular cfp and rp are evident in the dorsal views of the $C$. comensis complex, a defining characteristic of this genus. In light microscopy, variations in valve morphology are indistinguishable $(j-q)$. The larger specimen $(j)$ can be considered closer to $C$. pseudocomenesis. Individuals of small colonial Fragilariaceae (Fragilaria s.1.) include: Staurosirella pinnata in valve view $(r)$, dorsal view $(s, t, v$, and $w$ ), and girdle view (u); Staurosira construens var. venter in valve view $(x)$, dorsal view (y), and girdle view (z); Pseudostaurosira pseudoconstruens in dorsal view $\left(a^{\prime}\right.$ and $\left.b^{\prime}\right)$; Pseudostaurosira brevistriata in dorsal view $\left(c^{\prime}\right)$. Interior views of these taxa all reveal the presence of apical pore fields.
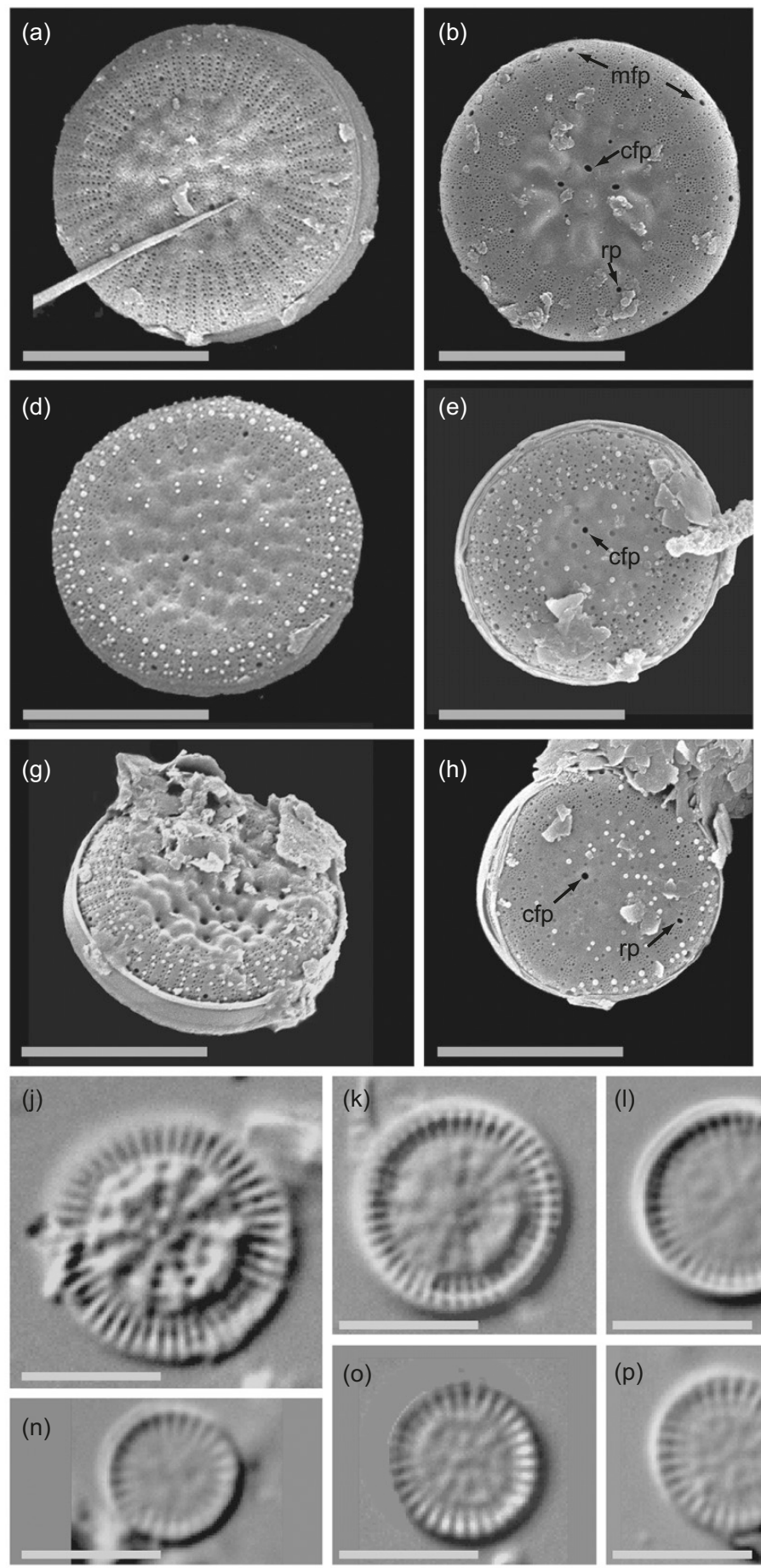
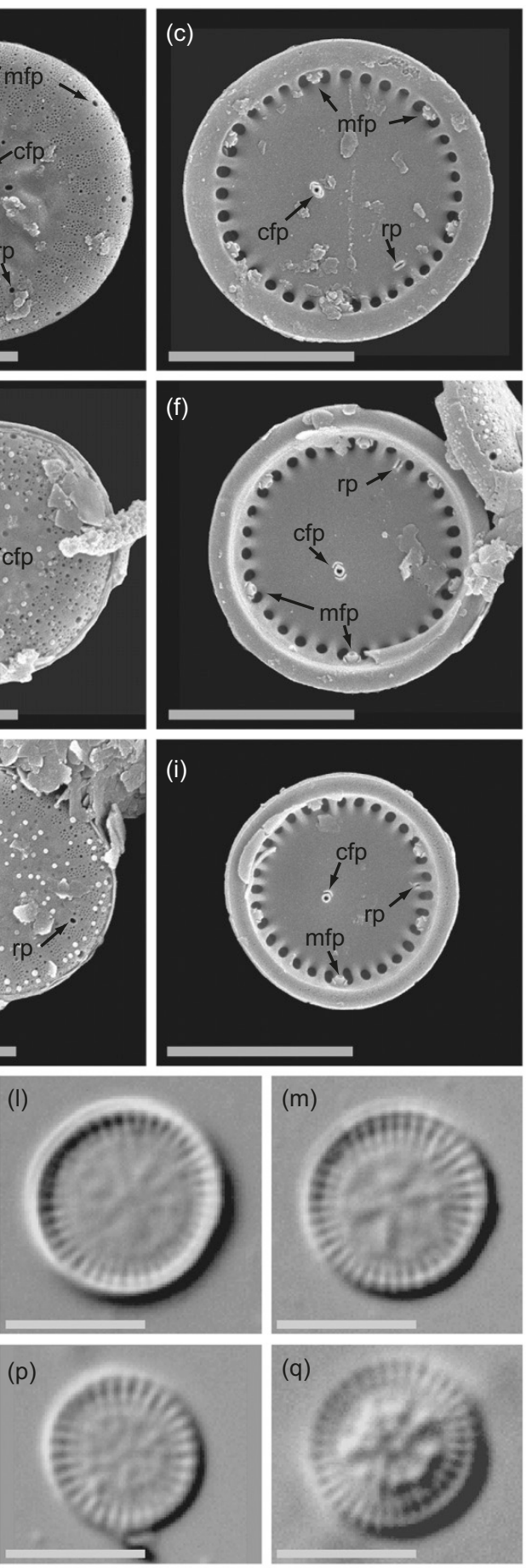

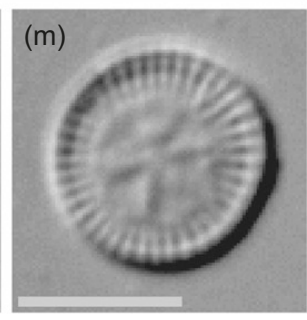

(q)
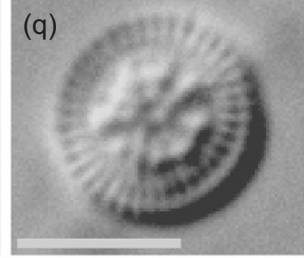
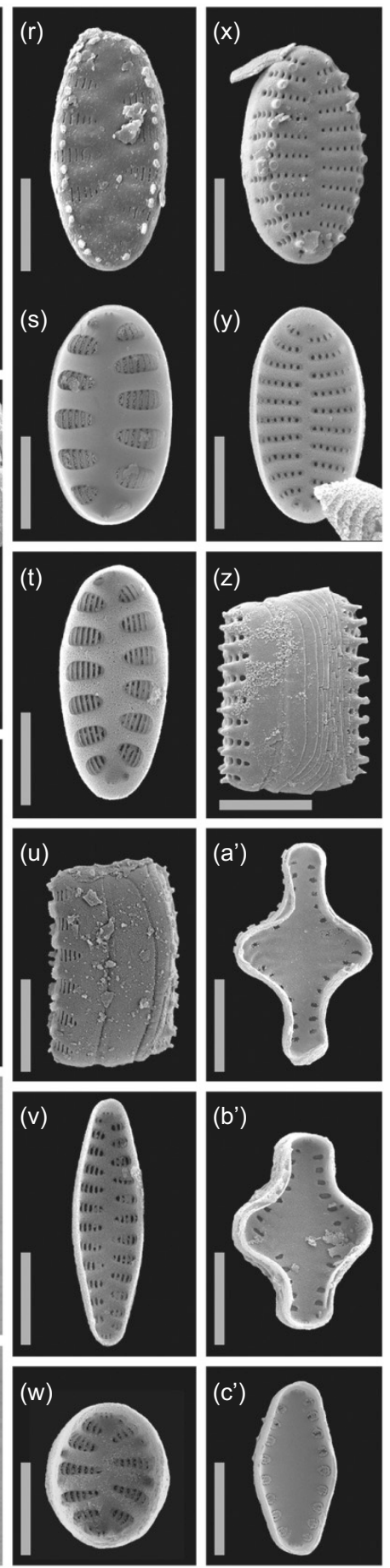
Fig. 8. Rate-of-change in diatom (black line) and pigment (grey line) assemblages over the last 500 years for Curator Lake $(a)$ and McConnell Lake (b).

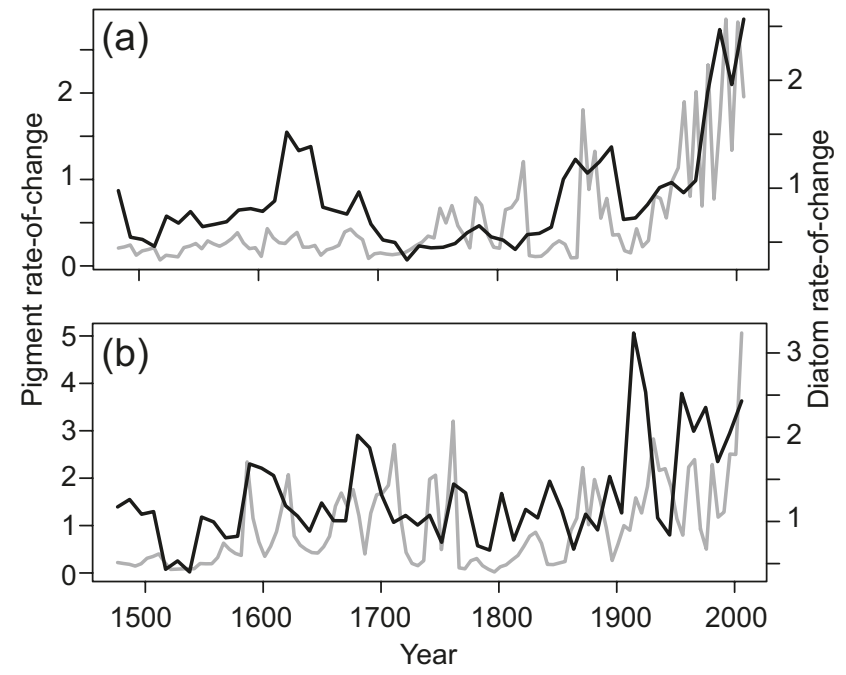

sediment Tchl $(r=0.52 ; p=0.027)$, which has also been shown by Vinebrooke et al. (2010) to correlate with dendroclimatic reconstructions (Luckman and Wilson 2005) spanning the length of the core. We were unable to find further correlations with the regional dendroclimatic record (Fig. 9b). The activity of the nearby Cavell and Centre Glaciers during the LIA suggest that colder temperatures prevailed in the mid-17th, early 18th, and mid-19th centuries (Luckman 2000). However, given the complacent sedimentology of our core (\% OM and percent carbonate), there appears to have been little glacial activity directly impacting Curator Lake and the catchment. The rate-of-change in the aquatic ecosystem of Curator Lake shows little change during the colder periods of regional glacial activity, with periods of instability that correlate with the onset (early 1600s) and subsidence (late 1800s) of the LIA. The late 20th century change is considerably greater and more variable than that observed during the LIA, suggesting the temperature during this period has perhaps elicited a threshold response. Based on the abundance of the Cyclotella comensis complex, which represents increased temperatures and a stratified water column, the marked post-1980 increase suggests climate warming at $\mathrm{Cu}$ rator Lake is beyond any interval of the prior $\sim 500$ years.

Relative to Curator Lake, the climate signal expressed at McConnell Lake is more closely mediated by catchment processes, in particular those associated with the headwall glacier. Shifts in the diatom assemblages suggest an indirect link to climate, through the influence of glacial activity and hydrology within the catchment, however there are no significant relationships between sediment biological proxies and instrumental or dendroclimatic records. The dramatic shift from a benthic dominated assemblage to the Cyclotella comensis complex at $\sim 1910$ coincides with a distinct change in sedimentology (increased organic content) and enhanced whole-lake primary production. This shift is coincident with reduced glacial inputs (rock flour), which likely caused associated decreases in lake turbidity and increased light penetration, stimulating primary production. Prior to this shift (late 19th century) the sedimentation rate in McConnell Lake increases, a response that has been associated with glacial re-
Fig. 9. Summary of relationships between abiotic drivers and algal responses. (a) Jasper MAT (grey line) and Curator Lake diatom community turnover (black line; DCA axis 1 scores). (b) Dendroclimatic summer maximum temperature anomalies (grey line) and Curator Lake diatom turnover (black line). (c) Sedimentary $\delta^{15} \mathrm{~N}$ record (grey line) in McConnell Lake and zeaxanthin concentrations (black line) attributed to picocyanobacteria. (d) Zeaxanthin (black line) and the Cyclotella comensis complex (grey line) in McConnell Lake provide evidence of emerging competition between picocyanobacteria and planktonic diatoms during the 20th century.
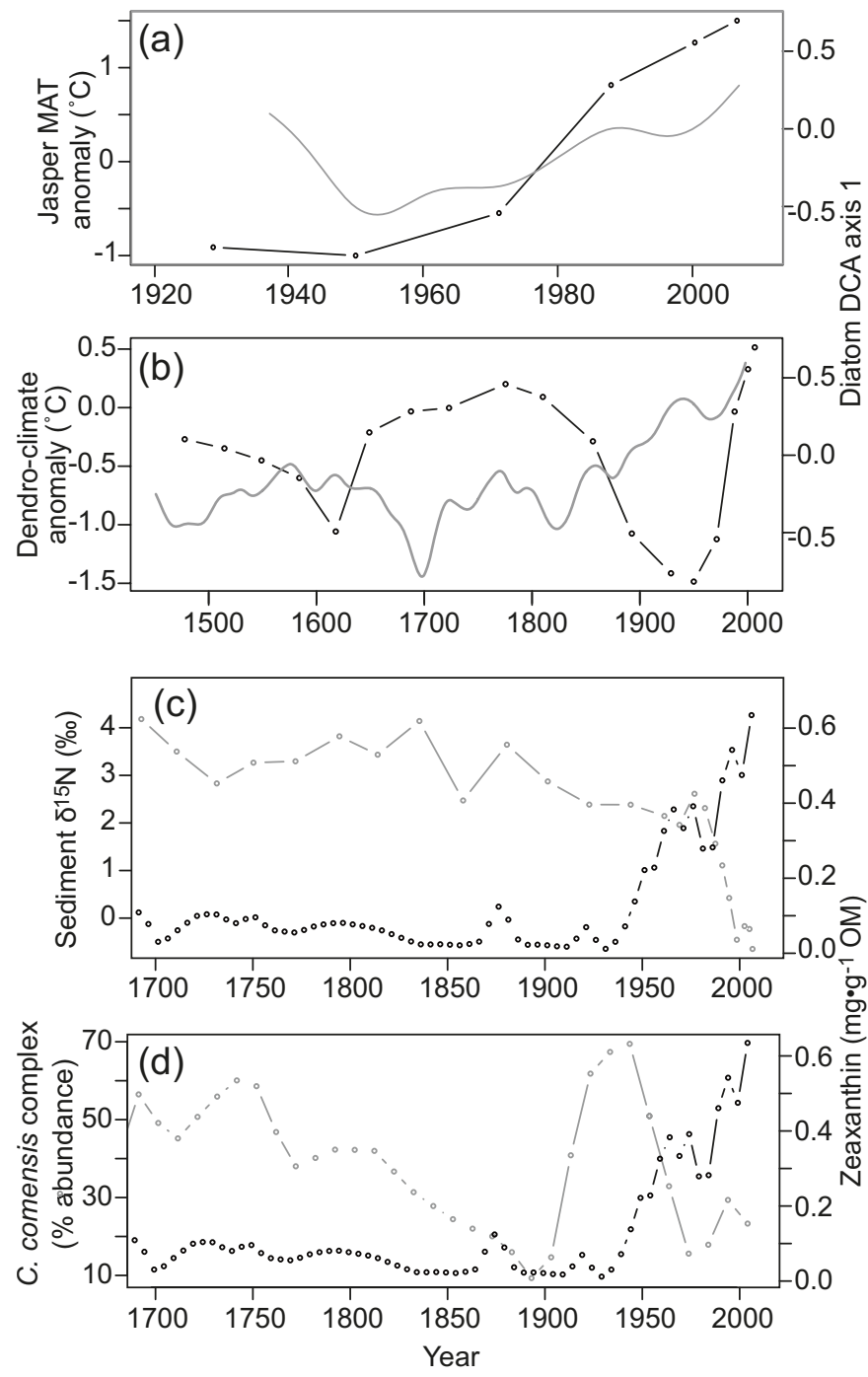

cession during a similar time period in the nearby Hector Lake (Leonard 1997). The maximum $\% \mathrm{CO}_{3}$ in the McConnell Lake core coincides with the LIA maximum during 1830-1860 for this region (Luckman 2000), supporting the clear influence of glacial activity on sedimentation in McConnell Lake and suggesting a similar timing of the LIA maximum in the basin. The regional LIA maximum also coincides with a reduction in the $C$. comensis complex and strong dominance by Staurosirella pinnata, and some of the lowest whole-lake primary production of the last 500 years in McConnell Lake. Together the response of the diatom communities and primary production shows that the aquatic ecosystem of McConnell Lake is closely tied to the surrounding catchment. 
The post-1910 section of the McConnell Lake core records an increase in organic sediment as the glaciers ablate. The increase in primary production is attributable to sulfur-reducing phototrophic bacteria (recorded as monomers of bacteriochlorophylls), picocyanobacteria (recorded by zeaxanthin concentrations), and planktonic diatoms. The dominance by the C. comensis complex lasts $\sim 60$ years (until 1970), at which time the benthic communities become dominant. With increased clarity of the water column and strong summer stratification, it is possible that benthic growth has been stimulated by an expansion of the lake's photic zone. Another plausible mechanism is that phototrophic bacteria blooms are out-competing planktonic diatoms for light and nutrients (Fig. 9d). Cyclotella comensis require a strongly stratified water column, which also provides an ideal habitat for deepwater sulfur-reducing phototrophic bacteria that thrive if the photosynthetic compensation depth extends well into anoxic hypolimnion. Because both may bloom in the late summer in alpine lakes (Lotter and Bigler 2000; Lafrançois et al. 2003), intense competition for resources is predicted. Experimental mesocosms have shown that phototrophic bacterial responses in alpine lakes are stimulated by increased $\mathrm{Nr}$ concentrations (Lafrançois et al. 2003; Nydick et al. 2004), whereas $C$. comensis is only a strong competitor for $\mathrm{Nr}$ during low $\mathrm{N}: \mathrm{P}$ conditions (Winder et al. 2009). We therefore need to consider in detail the influence of changing Nr inputs to McConnell Lake during the post-1970 period, when $C$. comensis abundance is low.

\section{$\mathrm{N}$ cycling, atmospheric $\mathrm{Nr}$ deposition, and nutrient limitation}

Increases in atmospheric anthropogenic $\mathrm{Nr}$ have been recorded by deviations in $\mathrm{N}$ stable isotopic ratios from lake sediments (Wolfe et al. 2003), tree-rings (Savard et al. 2009), and Greenland ice cores (Hastings et al. 2009). In lake sediments, overprinting of the primary isotopic signal by organic matter diagenesis is a constant concern (Peterson and Fry 1987; Gälman et al. 2009), although, these processes are typically of lesser magnitude than the isotopic signature of source Nr. It is also noted that the principal diagenetic processes in lake sediments generally exploit ${ }^{14} \mathrm{~N}$ preferentially, leaving the substrate enriched with respect to ${ }^{15} \mathrm{~N}$. This is the opposite of trends observed in association with anthropogenic $\mathrm{Nr}$ sources (Enders et al. 2008). We also note that changes in the sparse catchment vegetation should not exert a significant influence on the $\delta^{15} \mathrm{~N}$ of dissolved $\mathrm{N}$ within either lake, similar to findings of other lakes above tree line in the Canadian Rocky Mountains (Bunting et al. 2010).

Although both Curator and McConnell lakes produce comparable background sediment $\delta^{15} \mathrm{~N}(\sim 3.5 \%$ ) , it is only in the McConnell Lake sequence that recent rapid declines in sediment isotopic values are observed, in the order of $3.0 \%$. Both lakes are likely to receive $\mathrm{Nr}$ and other pollutants from regional sources including transportation (the TransCanada Highway and Icefields Parkway), industrial processes (cement production in the Bow River valley), and historically coal mining. McConnell Lake is the more proximal to these sources, and here sediment $\delta^{15} \mathrm{~N}$ begins to decline directionally after 1910, followed by a dramatic isotopic depletion post-1970. This record contains two important elements con- cerning $\mathrm{N}$ cycling, which much be considered with the realization that the $\delta^{15} \mathrm{~N}$ profile from Curator Lake, $\sim 200 \mathrm{~km}$ to the north, does not vary significantly over the last $\sim 500$ years; we infer that no dramatic change in $\mathrm{Nr}$ source or cycling has occurred in Curator Lake despite climate-driven changes in primary production and diatom composition. First, the McConnell Lake $\delta^{15} \mathrm{~N}$ profile parallels the course of ablation of the catchment's glaciers closely, suggesting that $\mathrm{Nr}$ archived in glacier ice is relegated to surface waters upon melt. It has been established that glacially influenced lakes have consistently higher $\mathrm{NO}_{3}{ }^{-}$concentrations relative to nearby nonglacial counterparts (Saros et al. 2010). This partially explains the absence of any changes in sediment $\delta^{15} \mathrm{~N}$ of Curator Lake. Secondly, the interval of greatest sediment $\delta^{15} \mathrm{~N}$ depletion in McConnell Lake occurs after 1970 $(\sim 3 \%$ ) , coinciding closely with increased picocyanobacterial production recorded as zeaxanthin (Fig. 9). Increased picocyanobacteria production is likely being driven by greater $\mathrm{Nr}$ inputs and thermal stratification. Because cyanobacterial metabolism fractionates very little, increased representation of this $\mathrm{Nr}$ source in sediment organic matter will likely reduce bulk sediment $\delta^{15} \mathrm{~N}$ (Peterson and Fry 1987). This is another difference with Curator Lake, for which cyanobacteria are not a substantial component of the algal community.

High $\mathrm{Nr}$ deposition in the southern Rocky Mountains has been implicated in shifting nutrient limitation of phytoplankton from $\mathrm{N}$ to $\mathrm{P}$ (Elser et al. 2009b). Water chemistry and evidence from nutrient bioassays reveals strong $\mathrm{P}$ limitation in both Curator and McConnell lakes (Murphy et al. 2010), but the stability of the Curator Lake $\delta^{15} \mathrm{~N}$ record suggests this has been the prevailing resource limitation for the last $\sim 500$ years. This is because the sudden alleviation of $\mathrm{N}$ limitation should result in a measurable $\delta^{15} \mathrm{~N}$ response as the ability of algae to discriminate against ${ }^{15} \mathrm{~N}$ increases (Teranes and Bernasconi 2000). Because the post-1910 isotopic depletion observed in McConnell Lake sediment may be attributed to the release of legacy $\mathrm{Nr}$ from melting snow and ice, it is likely that $\mathrm{P}$ limitation has intensified in this lake. Increased $\mathrm{Nr}$ availability that induced wholesale shifts in phytoplankton dominance patterns, is likely the primary control over the McConnell Lake $\delta^{15} \mathrm{~N}$ stratigraphy, indicating profound shifts in $\mathrm{N}$ cycling. The absence of these processes in Curator Lake, which has nonetheless changed markedly in other ways, illustrates how differential responses may arise in superficially similar lake ecosystems subjected to the same suite of stressors.

\section{Mediating effects of the lake catchment}

Sediments from Curator and McConnell lakes preserve evidence for a range of ecosystem responses during recent centuries, which we feel are strongly mediated by lake catchment processes. Although the lakes studied are similar with respect to size, basin morphology, and water chemistry, they have been variably influenced by similar abiotic drivers. Major shifts are temporally asynchronous and expressed differentially among photoautotrophic groups (e.g., diatoms and phototrophic bacteria). These findings highlight how contextdependent the response of alpine lakes to anthropogenic forcing can be. Despite these complexities, there is overwhelming evidence supporting the notion of accelerated environmental changes since the mid-20th century, in keeping with the gen- 
eral trend observed across remote lakes of the northern hemisphere (Hobbs et al. 2010a). It remains unclear exactly what future ecological trajectories these lakes will follow. Future climate warming, in many cases associated with the reduction of hydrological inputs from snow and ice, will likely create positive feedbacks involving increased primary production and organic matter supply to sediments. It is unclear what continued biological turnover will mean for the upper trophic levels and the health of the aquatic ecosystem as climate warming continues unabated.

\section{Acknowledgements}

The authors thank Erin Doxsey-Whitfield and Suzanne McGowan for assistance in the field and Colin Cooke, Mark Graham, Patrick Thompson, David Harris, and Collin Quarrie for laboratory assistance. The authors thank three anonymous reviewers for constructive comments that improved this manuscript. Funding was provided by the Alberta Water Research Institute and the Natural Sciences and Engineering Research Council of Canada (NSERC).

\section{References}

Appleby, P.G. 2010. Chronostragraphic techniques in recent sediments. In Tracking environmental change using lake sediments. Basin analysis, coring, and chronological techniques. Vol 1. Edited by W.M. Last and J.P. Smol. Kluwer Academic, Dordrecht, the Netherlands. pp. 171-203.

Appleby, P.G., and Oldfield, F. 1978. The calculation of lead-210 dates assuming a constant rate of supply of unsupported ${ }^{210} \mathrm{~Pb}$ to the sediment. Catena, 5(1): 1-8. doi:10.1016/S0341-8162(78) 80002-2.

Battarbee, R.W., Jones, V.J., Flower, R.J., Cameron, N.G., Bennion, H., Carvalho, L., and Juggins, S. 2001. Diatoms. In Tracking environmental change using lake sediments. Terrestrial, algal, and siliceous indicators. Vol. 3. Edited by J.P. Smol, H.J.B. Birks, and W.M. Last. Kluwer Academic Publishers, Dortrecht, the Netherlands. pp. 155-202.

Bergström, A.K., and Jansson, M. 2006. Atmospheric nitrogen deposition has caused nitrogen enrichment and eutrophication of lakes in the northern hemisphere. Glob. Change Biol. 12(4): 635643. doi:10.1111/j.1365-2486.2006.01129.x.

Binford, M. 1990. Calculation and uncertainty analysis of $\mathrm{Pb} 210$ dates for PIRLA project lake sediment cores. J. Paleolimnol. 3(3): 253-267. doi:10.1007/BF00219461.

Birks, H.J.B., and Line, J.M. 1992. The use of rarefaction analysis for estimating palynological richness from Quaternary pollen-analytical data. Holocene, 2: 1-10.

Bunting, L., Leavitt, P.R., Weidman, R.P., and Vinebrooke, R.D. 2010. Regulation of the nitrogen biogeochemistry of mountain lakes by subsidies of terrestrial dissolved organic matter and the implications for climate studies. Limnol. Oceanogr. 55(1): 333345. doi:10.4319/lo.2010.55.1.0333.

Cremer, H., Wagner, B., Melles, M., and Hubberten, H.W. 2001. The postglacial environmental development of Raffles S $\varnothing$, East Greenland: inferences from a 10,000 year diatom record. J. Paleolimnol. 26(1): 67-87. doi:10.1023/A:1011179321529.

Davidson, E.A. 2009. The contribution of manure and fertilizer nitrogen to atmospheric nitrous oxide since 1860. Nat. Geosci. 2(9): 659-662. doi:10.1038/ngeo608.

Desloges, J.R., and Gilbert, R. 1995. The sedimentary record of Moose Lake: implications for late-glacial and Little Ice Age glacier activity in the Mount Robson Area, British Columbia. Can. J. Earth Sci. 32: 65-78.

Elser, J.J., Kyle, M., Steger, L., Nydick, K.R., and Baron, J.S. $2009 a$. Nutrient availability and phytoplankton nutrient limitation across a gradient of atmospheric nitrogen deposition. Ecology, 90(11): 3062-3073. doi:10.1890/08-1742.1. PMID:19967862.

Elser, J.J., Andersen, J., Baron, J.S., Bergström, A., Jansson, M., Kyle, M., Nydick, K.R., Steger, L., and Hessen, D. 2009b. Shifts in lake $\mathrm{N}: \mathrm{P}$ stoichiometry and nutrient limitation driven by atmospheric nitrogen deposition. Science, 326(5954): 835-837. doi:10.1126/science.1176199. PMID:19892979.

Enders, S., Pagani, M., Pantoja, S., Baron, J.S., Wolfe, A.P., Pedentchouk, N., and Nuñez, L. 2008. Compound-specific stable isotopes of organic compounds from lake sediments track recent environmental changes in an alpine ecosystem, Rocky Mountain National Park, Colorado. Limnol. Oceanogr. 53(4): 1468-1478. doi:10.4319/lo.2008.53.4.1468.

Falkowski, P., Scholes, R.J., Boyle, E., Canadell, J., Canfield, D., Elser, J., Gruber, N., Hibbard, K., Högberg, P., Linder, S., Mackenzie , F.T., Moore, B., Pedersen, T., Rosenthal, Y., Seitzinger, S., Smetacek, V., and Steffen, W. 2000. The global carbon cycle: a test of our knowledge of earth as a system. Science, 290(5490): 291-296. doi:10.1126/science.290.5490.291. PMID: 11030643.

Fallu, M.A., Allaire, N., and Pienitz, R. 2000. Freshwater Diatoms from northern Québec and Labrador (Canada): species-environment relationships in lakes of boreal forest, forest-tundra and tundra regions. Bibliotheca Diatomologica Band 45. E. Schweizerbart, Germany.

Flower, R., and Likhoshway, Y. 1993. An investigation of diatom preservation in Lake Baikal. In Fifth Workshop on Diatom Algae. Edited by M.A. Grachev. Russian Botanical Society, Irkutsk, Russia. pp. 77-78.

Galloway, J.N., Dentener, F.J., Capone, D.G., Boyer, E.W., Howarth, R.W., Seitzinger, S.P., Asner, G.P., Cleveland, C.C., Green, P.A., Holland, E.A., Karl, D.M., Michaels, A.F., Porter, J.H., Townsend, A.R., and Vörösmarty, V.J. 2004. Nitrogen cycles: past, present, and future. Biogeochemistry, 70: 153-226. doi:10.1007/s10533004-0370-0.

Gälman, V., Rydberg, J., and Bigler, C. 2009. Decadal diagenetic effects on $\delta^{13} \mathrm{C}$ and $\delta^{15} \mathrm{~N}$ studied in varved lake sediment. Limnol. Oceanogr. 54(3): 917-924. doi:10.4319/lo.2009.54.3.0917.

Glew, J.R., Smol, J.P., and Last, W.M. 2001. Sediment core collection and extrusion. In Tracking environmental change using lake sediments. Basin analysis, coring, and chronological techniques. Vol. 1. Edited by W.M. Last and J.P. Smol. Kluwer Academic Publishers, Dordrecht, the Netherlands. pp. 73-106.

Hall, R., Leavitt, P.R., Quinlan, R., Dixit, A., and Smol, J.P. 1999. Effects of agriculture, urbanization, and climate on water quality in the northern Great Plains. Limnol. Oceanogr. 44(3, part 2): 739 756. doi:10.4319/lo.1999.44.3_part_2.0739.

Hastings, M.G., Jarvis, J.C., and Steig, E.G. 2009. Anthropogenic impacts on nitrogen isotopes of ice-core nitrate. Science, 324(5932): 1288. doi:10.1126/science.1170510. PMID:19498161.

Heiri, O., Lotter, A.F., and Lemcke, G. 2001. Loss on ignition as a method for estimating organic and carbonate content in sediments: reproducibility and comparability of results. J. Paleolimnol. 25(1): 101-110. doi:10.1023/A:1008119611481.

Hill, M.O., and Gauch, H.G., Jr. 1980. Detrended correspondenceanalysis - an improved ordination technique. Vegetatio, 42(1-3): 47-58. doi:10.1007/BF00048870.

Hobbs, W.O., Telford, R.J., Birks, H.J.B., Saros, J.E., Hazewinkel, R.R.O., Perren, B.B., Saulnier-Talbot, É., and Wolfe, A.P. $2010 a$. Quantifying recent ecological changes in remote lakes of North 
America and Greenland using sediment diatom assemblages. PLoS ONE, 5(4): e10026. doi:10.1371/journal.pone.0010026. PMID:20368811.

Hobbs, W.O., Lalonde, S.V., Vinebrooke, R.D., Konhauser, K.O., Weidman, R.P., Graham, M.D., and Wolfe, A.P. 2010b. Algal-silica cycling and pigment diagenesis in recent alpine lake sediments: mechanisms and paleoecological implications. J. Paleolimnol. 44(2): 613-628. doi:10.1007/s10933-010-9441-5.

Jacobson, G.L., and Grimm, E.C. 1986. A numerical analysis of Holocene forest and prairie vegetation in central Minnesota. Ecology, 67(4): 958-966. doi:10.2307/1939818.

Jeffrey, S.W., Mantoura, R.F.C., and Wright, S.W. 2005. Phytoplankton pigments in oceanography: guidelines to modern methods. 2nd ed. UNESCO Publishing, Paris, France.

Karst-Riddoch, T.L., Pisaric, M.F.J., and Smol, J.P.S. 2005. Diatom responses to 20th century climate-related environmental changes in high-elevation mountain lakes of the northern Canadian Cordillera. J. Paleolimnol. 33(3): 265-282. doi:10.1007/s10933004-5334-9.

Krammer, K., and Lange-Bertalot, H. 1986. Bacillariophyceae. 1. Teil: Naviculaceae. In Süßwasserflora von Mitteleuropa. Edited by H. Ettl, G. Gärtner, J. Gerloff, H. Heynig, and D. Mollenhauer. Band 2/1, Gustav Fischer Verlag, Stuttgart, Germany/New York, N.Y.

Krammer, K., and Lange-Bertalot, H. 1988. Bacillariophyceae. 2. Teil: Bacillariaceae, Epithemiaceae, Surirellaceae. In Süßwasserflora von Mitteleuropa. Edited by H. Ettl, G. Gärtner, J. Gerloff, H. Heynig, and D. Mollenhauer. Band 2/2, Gustav Fischer Verlag, Stuttgart, Germany/New York, N.Y.

Krammer, K., and Lange-Bertalot, H. 1991a. Bacillariophyceae. 3. Teil: Centrales, Fragilariaceae, Eunotiaceae. In Süßwasserflora von Mitteleuropa. Edited by H. Ettl, G. Gärtner, J. Gerloff, H. Heynig, and D. Mollenhauer. Band 2/3, Gustav Fischer Verlag, Stuttgart/ Jena, Germany.

Krammer, K., and Lange-Bertalot, H. 1991b. Bacillariophyceae. 4. Teil: Achnanthaceae Kritische Ergäzungen zu Navicula (Lineolatae) und Gomphonema. In Süßwasserflora von Mitteleuropa. Edited by H. Ettl, G. Gärtner, J. Gerloff, H. Heynig, and D. Mollenhauer. Band 2/4, Gustav Fischer Verlag, Stuttgart/Jena, Germany.

Lafrançois, B.M., Nydick, K.R., and Caruso, B. 2003. Influence of nitrogen on phytoplankton biomass and community composition in fifteen Snowy Range Lakes (Wyoming, USA). Arct. Antarct. Alp. Res. 35(4): 499-508. doi:10.1657/1523-0430(2003)035 [0499:IONOPB]2.0.CO;2.

Landers, D.H., Simonich, S.L., Jaffe, D.A., Geiser, L.H., Campbell, D.H., Schwindt, A.R., Schreck, C.B., Kent, M.L., Hafner, W.D., Taylor, H.E., Hageman, K.J., Usenko, S., Ackerman, L.K., Schrlau, J.E., Rose, N.L., Blett, T.F., and Erway, M.M. 2008. The Fate, Transport, and Ecological Impacts of Airborne Contaminants in Western National Parks (USA). EPA/600/R-07/ 138. US Environmental Protection Agency, Office of Research and Development, NHEERL, Western Ecology Division, Corvallis, Ore.

Last, W.M., and Smol, J.P. (Editors). 2001 Tracking environmental change using lake sediments, volume 2: physical and geochemical methods. Kluwer Academic Publishers, Dortrecht, the Netherlands.

Leonard, E.M. 1997. The relationship between glacial activity and sediment production: evidence from a 4450-year varve record of Neoglacial sedimentation in Hector Lake, Alberta. J. Paleolimnol. 17(3): 319-330. doi:10.1023/A:1007948327654.

Lotter, A.F., and Bigler, C. 2000. Do diatoms in the Swiss Alps reflect the length of ice-cover? Aquat. Sci. 62(2): 125-141. doi:10. 1007/s000270050002.
Lotter, A.F., Ammann, B., and Sturm, M. 1992. Rates of change and chronological problems during the late-glacial period. Clim. Dyn. 6(3-4): 233-239. doi:10.1007/BF00193536.

Luckman, B.H. 2000. The Little Ice Age in the Canadian Rockies. Geomorphology, 32(3-4): 357-384. doi:10.1016/S0169-555X(99) 00104-X.

Luckman, B.H., and Wilson, R.J.S. 2005. Summer temperatures in the Canadian Rockies during the last millennium: a revised record. Clim. Dyn. 24(2-3): 131-144. doi:10.1007/s00382-004-0511-0.

Moser, K.A., Smol, J.P., and MacDonald, G.M. 2004. Ecology and distribution of diatoms from boreal forest lakes in Wood Buffalo National Park, Northern Alberta and the Northwest Territories, Canada. Academy of Natural Sciences, Philadelphia, Pa. No. 22.

Murphy, C.A., Thompson, P.L., and Vinebrooke, R.D. 2010 Assessing the sensitivity of alpine lakes and ponds to nitrogen deposition in the Canadian Rocky Mountains. Hydrobiologia, 648(1): 83-90. doi:10.1007/s10750-010-0146-6.

Nydick, K.R., Lafrançois, B.M., Baron, J.S., and Johnson, B. 2004. Nitrogen regulation of algal biomass, productivity, and composition in shallow mountain lakes, Snowy Range, Wyoming, USA. Can. J. Fish. Aquat. Sci. 61(7): 1256-1268. doi:10.1139/f04-085.

Paillard, D., Labeyrie, L., and Yiou, P. 1996. Macintosh program performs time-series analysis. Eos Trans. AGU, 77(39): 379. doi:10.1029/96EO00259.

Parker, B.R., Vinebrooke, R.D., and Schindler, D.W. 2008. Recent climate extremes alter alpine lake ecosystems. Proc. Natl. Acad. Sci. U.S.A. 105(35): 12927-12931. doi:10.1073/pnas.0806481105. PMID:18725641.

Peterson, B., and Fry, B. 1987. Stable isotopes in ecosystem studies. Annu. Rev. Ecol. Syst. 18(1): 293-320. doi:10.1146/annurev.es. 18.110187.001453.

R Development Core Team. 2010. R: a language and environment for statistical computing. R Foundation for Statistical Computing, Vienna, Austria. Available from http://www.R-project.org.

Reasoner, M.A., and Hickman, M. 1989. Late Quaternary environmental change in the Lake O'Hara region, Yoho National Park, British Columbia. Palaeogeogr. Palaeoclimatol. Palaeoecol. 72: 291-316. doi:10.1016/0031-0182(89)90149-1.

Rühland, K., Paterson, A.M., and Smol, J.P. 2008. Hemispheric-scale patterns of climate-related shifts in planktonic diatoms from North American and European lakes. Glob. Change Biol. 14: 1-15.

Ryves, D., Juggins, S., Fritz, S., and Battarbee, R. 2001. Experimental diatom dissolution and the quantification of microfossil preservation in sediments. Palaeogeogr. Palaeoclimatol. Paleoecol. 172(12): 99-113. doi:10.1016/S0031-0182(01)00273-5.

Saros, J.E., Rose, K.C., Clow, D.W., Stephens, V.C., Nurse, A.B., Arnett, H.A., Stone, J.R., Williamson, C.E., and Wolfe, A.P. 2010. Melting alpine glaciers enrich high-elevation lakes with reactive nitrogen. Environ. Sci. Technol. 44(13): 4891-4896. doi:10.1021/ es100147j. PMID:20527763.

Saros, J.E., Clow, D.W., Blett, T., and Wolfe, A.P. 2011. Critical nitrogen deposition loads in high-elevation lakes of the western US inferred from paleolimnological records. Water Air Soil Pollut. 216(1-4): 193-202. doi:10.1007/s11270-010-0526-6.

Savard, M.M., Bégin, C., Smirnoff, A., Marion, J., and RiouxPaquette, E. 2009. Tree-ring nitrogen isotopes reflect anthropogenic $\mathrm{NO}_{x}$ emissions and climatic effects. Environ. Sci. Technol. 43(3): 604-609. doi:10.1021/es802437k. PMID:19244990.

Schindler, D.W., and Donahue, W.F. 2006. An impending water crisis in Canada's western prairie provinces. Proc. Natl. Acad. Sci. U.S.A. 103(19): 7210-7216. doi:10.1073/pnas.0601568103. PMID: 16606829 .

Schindler, D.W., Dillon, P.J., and Schreier, H. 2006. A review of anthropogenic sources of nitrogen and their effects on Canadian 
aquatic ecosystems. Biogeochemistry, 79(1-2): 25-44. doi:10. 1007/s10533-006-9001-2.

Smol, J.P. 2010. The power of the past: using sediments to track the effects of multiple stressors on lake ecosystems. Freshw. Biol. 55: 43-59. doi:10.1111/j.1365-2427.2009.02373.x.

Smol, J.P., Birks, H.J.B., and Last, W.M. (Editors). 2001. Tracking environmental change using lake sediments, volume 3: terrestrial, algal, and siliceous indicators. Kluwer Academic Publishers, Dortrecht, the Netherlands.

Teranes, J.L., and Bernasconi, S.M. 2000. The record of nitrate utilization and productivity limitation provided by $\delta^{15} \mathrm{~N}$ values in lake organic matter - a study of sediment trap and core sediments from Baldeggersee, Switzerland. Limnol. Oceanogr. 45(4): 801813. doi:10.4319/lo.2000.45.4.0801.

Vinebrooke, R., Dixit, S., Graham, M., Gunn, J., Chen, Y.-W., and Belzile, N. 2002. Whole-lake algal responses to a century of acidic industrial deposition on the Canadian Shield. Can. J. Fish. Aquat. Sci. 59(3): 483-493. doi:10.1139/f02-025.

Vinebrooke, R.D., Cottingham, K.L., Norberg, J., Scheffer, M., Dodson, S.I., Maberly, S.C., and Sommer, U. 2004. Impacts of multiple stressors on biodiversity and ecosystem functioning: the role of species co-tolerance. Oikos, 104: 451-457. doi:10.1111/j. 0030-1299.2004.13255.x.

Vinebrooke, R.D., Thompson, P.L., Hobbs, W.O., Luckman, B.H., Graham, M.D., and Wolfe, A.P. 2010. Glacially mediated impacts of climate warming on alpine lakes of the Canadian Rocky Mountains. Verh. Internat. Verein. Limnol. 30: 1449-1452.

Watson, E., and Luckman, B.H. 2004. Tree-ring-based mass-balance estimates for the past 300 years at Peyto Glacier, Alberta, Canada. Quat. Res. 62(1): 9-18. doi:10.1016/j.yqres.2004.04.007.

Williamson, C.E., Saros, J.E., and Schindler, D.E. 2009. Sentinels of change. Science, 323(5916): 887-888. doi:10.1126/science. 1169443. PMID:19213905.

Winder, M., Reuter, J.E., and Schladow, S.G. 2009. Lake warming favours small-sized planktonic diatom species. Proc. Biol. Sci. 276(1656): 427-435. doi:10.1098/rspb.2008.1200. PMID: 18812287.

Wolfe, A.P. 1997. On diatom concentrations in lake sediments: results from an inter-laboratory comparison and other tests performed on a uniform sample. J. Paleolimnol. 18(3): 261-268. doi:10.1023/ A: 1007937300347.

Wolfe, A.P., Van Gorp, A.C., and Baron, J.S. 2003. Recent ecological and biogeochemical changes in alpine lakes of Rocky Mountain National Park (Colorado, USA): a response to anthropogenic nitrogen deposition. Geobiology, 1(2): 153-168. doi:10.1046/j. 1472-4669.2003.00012.x.

Wunsam, S., Schmidt, R., and Klee, R. 1995. Cyclotella-taxa (Bacillariophyceae) in lakes of the Alpine region and their relationship to environmental variables. Aquat. Sci. 57(4): 360386. doi:10.1007/BF00878399. 